ECONOMIC GROWTH CENTER

YALE UNIVERSITY

P.O. Box 208269

New Haven, CT 06520-8269

http://www.econ.yale.edu/ egcenter/

CENTER DISCUSSION PAPER NO. 875

\title{
EVIDENCE OF RETURNS TO SCHOOLING IN AFRICA FROM HOUSEHOLD SURVEYS: MONITORING AND RESTRUCTURING THE MARKET FOR EDUCATION
}

\author{
T. Paul Schultz \\ Yale University
}

December 2003

Notes: Center Discussion Papers are preliminary materials circulated to stimulate discussions and critical comments.

Prepared for the African Economic Research Consortia meeting in Durban, South Africa, December 8, 2002. I have benefitted from the comments on an earlier version of this paper by David Bloom, Cheryl Doss, Germano Mwabu, Adebayo Aromolaran, Harounan Kazianga, a referee, and the participants at a conference on Higher Education and African Development held at Yale University, October 19-21, 2001. I appreciate Rockefeller Foundation support for training and research on the family in low-income countries on which this paper draws, and the invitation from AERC to participate in their meeting. I am solely responsible for remaining errors and shortcomings.

This paper can be downloaded without charge from the Social Science Research Network electronic library at: http://ssrn.com/abstract=487476

An index to papers in the Economic Growth Center Discussion Paper Series is located at: http://www.econ.yale.edu/ egcenter/research.htm 


\title{
Evidence of Returns to Schooling in Africa from Household Surveys: Monitoring and Restructuring the Market for Education
}

\section{T. Paul Schultz}

Yale University

\begin{abstract}
Wage-differentials by education of men and women are examined from African household surveys to suggest private wage returns to schooling. It is commonly asserted that returns are highest at primary school levels and decrease at secondary and postsecondary levels, whereas private returns in six African countries are today highest at the secondary and post secondary levels, and rates are similar for women as for men. The large public subsidies for postsecondary education in Africa, therefore, are not needed to motivate students to enroll, and those who have in the past enrolled in these levels of education are disproportionately from the better-educated families. Higher education in Africa could be more efficient and more equitably distributed if the children of well-educated parents paid the public costs of their schooling, and these tuition revenues facilitated the expansion of higher education and financed fellowships for children of the poor and less educated parents.
\end{abstract}

Keywords: Africa, Wage Returns to Schooling, Inequality, HIV/AIDS JEL codes: 015, 055, J31, J24 


\section{Introduction}

In the last two decades, many countries in Africa have had difficulty extending primary and secondary schooling to an increasing fraction of their youth, or in building high quality university training and parallel research institutions. Opinion is divided on how to refocus resources and determine priorities to improve the prospects for the future. This paper reviews some of the economic arguments for specific policies and examines empirical evidence that can be assembled from household surveys which may help assess the claims and counter-claims advanced for various proposals.

If "public good aspects" of human capital and positive social externalities of human capital are an important justification for public investments in education, have we empirically documented the magnitude of such social benefits to calibrate how public resource priorities should be influenced by these externalities? The justification of public expenditures on human capital requires not only that these investments earn a satisfactory overall social return (private returns plus net public spillovers), it also requires that the distribution of these social returns across individuals and groups in the society is equitable or narrows existing inequalities in society.

Education is sufficiently valued by most of the world's elite socioeconomic classes that these influential groups consume a disproportionate share of public sector resources in education, especially in higher education. What are the options for improving the personal distribution of benefits from public expenditures on education, and are there "best practices" which might be replicated in Africa to channel more of the benefits of education to the children of the poor? Can poor societies manage to achieve a more equitable access to higher education by quotas, targeted subsidies, scholarships, or student loans? Has the effort to reduce the educational gap between men and women been successful? How does the globalization of trade and capital markets, along with the decreasing cost of immigration, particularly for educated workers, change the landscape and modify the maneuverability of national educational policy in Africa and other regions where incomes are on average low?

I will focus mainly on the two salient economic criteria for performance of public policy, that of efficiency or increasing outputs for a given level of public and private costs of inputs, and of equity or increasing the share of the private net benefit (in excess of the private costs) received by the poorer strata of society. The poorer social strata include typically those families residing in rural areas and remote towns, and children born into families in which economic resources are least adequate, and to parents who are themselves the least educated in their birth cohort. The political 
institutions needed to achieve a more efficient and equitable educational system in Africa are likely to be paramount. But this paper, unfortunately, discusses only a few of the economic considerations.

\section{Schooling, Wages and Educational Priorities}

The criteria by which to set priorities in education involve both the tradeoffs between efficiency and equity, and also the evaluation of the costs and benefits of education to the private individual and to the broader society. Since the 1960s differences in wages between workers with different amounts of schooling have been viewed as private productive benefits from attending school, as represented in Table 1, cell 1A. ${ }^{1}$ Private costs of schooling are deducted from the benefits associated with wage differentials, properly discounting both costs and benefits to some initial decision point when the child may enroll in school. About half of the private costs of attending school is the productive value of the time that students spend traveling to school, in class and in studies, which their families forego if their children attend school (Table 1, 1B). Thus, even when schooling is provided by the state without charge, much of the total costs of schooling remain a private burden on the family. To enroll their children in school the family must value the gains their children are likely to receive from their schooling over their adult lifetimes, and the parents must be willing to reallocate their resources to make these schooling investments, and possibly borrow to make these investments which appear likely to enhance their children’s future productivity.

Mincer (1974) proposed a rough approximation for the financial private returns to education which can be readily estimated from a cross-sectional sample. Hundreds of household surveys from all regions of the world have been examined using his specification of the wage structure for both men and women. ${ }^{2}$

Estimates of private returns to schooling (Table 1, 1C) are inevitably compared with returns to durable physical capital investments, such as might be earned on industrial bonds. There are

\footnotetext{
$\mathbf{1}$ The differences in worker productivity by schooling, age, and sex were first used by T. W. Schultz (1961), Denison (1962), and Kuznets (1966) to attribute part of modern economic growth to the changing composition of the labor force in the United States and other countries. The conceptual and empirical analysis of the US 1940 Census cross tabulations of earnings led Becker (1964) to his calculation of an internal rate of return, which would over an individual's lifetime equate the opportunity cost of obtaining schooling to the discounted value of lifetime wage gains. Jorgenson (1995) has continued to extend this approach in his national income accounts for the United States.

2 Although there are additional questions to resolve in the study of women's wage structures with these empirical methods, the estimated wage returns to schooling for women are approximately equivalent to those for men, with occasionally the private wage returns being higher for women than men in those economies where women have not attained equal levels of schooling to men (Schultz, 1995). A major challenge is to deal with the potential bias introduced by the selection of the subsample of the population who work for a wage, and the selection process determining who receives more and less schooling.
} 
nonetheless many differences between human capital and financial assets, notably the lack of liquidity or marketability of human capital that alters its use as collateral. In addition many students undoubtedly enjoy being educated and their parents are happy to educate them, and these consumption and status benefits are expected to also boost their private demands for schooling in addition to the effects of productive benefits (Table 1, 1A).

From society’s viewpoint, moreover, the educational system requires public resources to build and maintain school structures, pay teacher salaries, purchase school supplies, and meet administrative expenses. The public sector may offset some of these educational outlays with school and examination fees, local taxes earmarked for education, and may recover in the future incremental taxes paid by students (Table 1, 2B). These taxes may increase with rising education, because better educated workers tend to allocate more of their time to work to "covered" jobs from which the government can deduct taxes, and because better educated workers are paid more per hour worked. However, governments in low income countries tend to collect a relatively small share of their revenues from personal income, wage, or consumption taxes (e.g. VAT), and hence do not in fact recover much of the costs of public education from such taxes (Burgess, 1997).

The social return to schooling is generally calculated by adding these public account costs and revenues associated with schooling (2C) to the private costs and wage returns (1C) on which Mincer's private wage return formulation is based. The resulting social returns to schooling (3C), neglecting initially the elusive social spillovers (3A) which are discussed later, tend to be lower than the private wage return as approximated by Mincer. Although public costs per student tend to be slightly larger for higher education than for primary and secondary education in high-income countries, the public costs for higher education in low-income countries can be 10 and 40 times larger than those for secondary and primary schools, respectively (Psacharapoulos and Woodhall, 1985). Thus the gap between private and social returns tend to be larger for higher education in low income countries.

Benefits of schooling, which accrue to individuals other than the student and her family, are called social spillovers or positive social externalities of schooling (2A). If the present discounted value of these social benefits of schooling exceeds public net expenditures on producing the schooling, the public sector receives a positive return on its outlays in the education sector (2C). If this public sector return exceeds the social cost of capital, or the burden of raising these revenues by taxation or foregoing other public programs, increased public outlays for the support of this form of schooling are justified on efficiency grounds alone. Some "market failure" may prevent families from privately investing the optimal amount in schooling, given the prevailing private return (1C). 
One possible market failure is that the student/family has imperfect information about the private returns to school enrollment and underestimate these returns, or the student/family may be unable to borrow to finance school attendance perhaps because they lack collateral. The poor are believed to be especially constrained in access to such credit, because human capital cannot generally be used as collateral by lending institutions or money-lenders. Public subsidies for education are less equally distributed at the level of higher education than they are at the primary and secondary education levels (Jimenez, 1987; Hinchliffe, 1993; Colclough, 1997; King, 1997; Tilak, 1997). Thus, high returns may strengthen an efficiency argument for public investment in higher education, but special policy instruments are then needed to avoid the consequence of increasing inequality in the personal distribution of income, if a disproportionate share of the benefits of higher education flows to the rich.

This human capital framework for analyzing education indicates that the design of educational policy should take into account both the private demand for schooling and the public supply of schooling. If the private returns to schooling are low (3C), and families do not demand more schooling for their children, an expansion of public expenditures on education may not increase enrollment, and building new schools is not a solution. The public coordination of supply must monitor the private demand, not only to forecast school utilization rates, but also to anticipate the private and social returns which can be expected for those individuals who are educated, and to forecast how enrollments are distributed across different socioeconomic groups in society.

\section{Social Externalities of Schooling}

It is widely observed that education is desired by families and by society for reasons other than simply its capacity to raise worker productivity. Human capital admittedly offers only a limited perspective on education, although one that can be quantified and monitored in the labor market over time, and contrasted between different levels of schooling and for different groups whose membership is fixed in the population. There are also many who see education as a merit good, defined as a good which all people deserve to receive. Nonetheless, setting social priorities is inescapable: How much and what kind of schooling should a country produce, given its available resources?

Social externalities from education are benefits not realized in terms of private human capital or consumption benefits accrued by those who make the sacrifices to obtain the education, nor are they realized in increased output and profits by firms which employ the more educated worker. They are hypothesized to account for "endogenous growth" which can coexist with competitive markets and increasing returns (Romer, 1986; Lucas, 1988). However, few studies have succeeded in 
empirically estimating these social external benefits of education, or even suggesting the context in which they are expected to be most salient, e.g. at the level of the nation state, city, or local community, or across certain segments of the labor force in a geographic market area.

Particular types of scientific education and allied research and development activities have been linked to the generation of social external benefits, because they produce productive knowledge which may diffuse relatively freely in society, and would therefore not be produced in sufficient amounts if left to private market incentives alone to encourage profitable production. Agricultural sciences and biotechnology develop new inputs for the farmer, such as high yielding varieties of crops and livestock, which raise outputs and reduce production costs and eventually reduce the price of agricultural commodities for the consumer. But these new agricultural inputs are often narrowly adapted to a specific latitude (i.e., length of day), climate, and local pests. For similar reasons, public health research may contribute to the improved design of local policy interventions which control endemic and epidemic diseases by intervening with tailor-made technologies and delivery systems. These public health inventions have their greatest effectiveness in a specific climate, where certain parasites are present, and where the population density and sanitation system has certain characteristics. Consequently, locally adapted control interventions guided by local policy evaluation studies are often valuable, which can be most cost-effective when they are coordinated through public health and medical training and research institutions.

The best documented examples of social externalities associated with schooling involve the link between the education of parents and home production, which primarily enhance the well being of family members, and primarily in the formation of human capital in children. Micro-empirical studies of child development find that increases in the schooling of the mother are associated with improvements in child developmental outcomes, and these effects tend to be larger than those associated with the same increases in the years of schooling of the father. The larger effects of the mother's schooling than the father's schooling are commonly observed whether the child development indicator is birth-weight, child survival, nutritional status as measured by height or weight-for-height given age, age of entry into school, school enrollment adjusted for age, or years of schooling completed upon reaching adulthood (Schultz, 2002). ${ }^{3}$ These human capital inter-

\section{3}

Unfortunately many empirical studies of the effect of parent schooling on child development are flawed from the perspective of this analysis, because they control for variables that are themselves likely to be affected by parent schooling. A deeper understanding of the marriage market might sharpen our insights into some of these connections and how gender differences in parent schooling contribute to child development. 
generational externalities of schooling favor social investments in women's schooling, but most of these studies have concentrated on the effects of primary and secondary education.

\section{Are Wage Differences by Education a Misleading Indicator of Productivity?}

According to some observers the current structure of wage rates by schooling, age, and sex in a low-income country does not represent an accurate picture of the productive gains that would be realized by increasing the supply of better-educated persons. For example, an analysis of Côte d'Ivoire reports earnings differentials which imply each year of schooling of a worker is associated with him or her receiving on average a 23 percent increment in earnings, after holding constant for other characteristics of the worker and the sector in which the worker is employed: formal/informal, government, public enterprise, or private firm. The authors conclude their discussion of their estimated "wage function" by attributing the high private rate of return to schooling to imperfections in the labor market. They caution that it is "reasonable to link this result to rigidity in salary scales." And without offering further evidence, the authors conclude that "there is probably considerable room for reduction in wages and salaries throughout the modern labor market that would make wages and salaries more competitive” (Berthelemy and Bourguignon, 1996, p.48). No description is provided of an empirical test for market wage "rigidity", or how they propose to achieve a "reduction in wages and salaries throughout the modern labor market”. The assumption that labor markets in low-income countries are seriously distorted (i.e., by unions, governments, and monopsonistic firms) has a long and influential history in development economics from Lewis (1954), to Fei and Ranis (1964), and Harris and Todaro (1970), but one that is rarely submitted to empirical testing. ${ }^{4}$

From the perspective of university administrators and personnel, the benefits of having more graduates of higher education in low-income countries extend well beyond the productive earning capacity of those who receive the higher education. The Task Force on Higher Education and Society (World Bank, 2000) argues that "Rate-of-return studies treat educated people as valuable only through their higher earnings and the greater tax revenues extracted by society. But educated people

4

Easterly (2001) summarizes the evidence from cross country regressions of growth on changes in educational attainment, which do not always find a positive partial correlation, which is viewed as challenging the idea that education contributes to growth. Anomalous estimates of cross country growth rates over time conditioned on changes over time in education may be partly explained by measurement error. Topel (1999) examines the specifications of some of these aggregate growth regressions and interprets the meaning of the empirical evidence in light of wage function estimates. 
clearly have many other effects on society: educated people are well-positioned to be economic and social entrepreneurs, having far reaching impact on the economic and social well-being of their communities. They are also vital to creating an environment in which economic development is possible. Good governance, strong institutions, and a developed infrastructure are all needed if business is to thrive -- and none of these is possible without highly educated people. Finally, rate-ofreturn analysis entirely misses the impact of university-based research on the economy -- a farreaching social benefit that is at the heart of any argument for developing strong higher educational systems” (World Bank, 2000, p.39). Unfortunately the Report does not offer quantitative evidence and analysis to support its conjectures. Household and labor force survey data in Africa in the last decade have been much improved, and the emerging wage patterns they reveal have significant implications for educational priorities.

\section{Household Survey Estimates of Wage Returns to Schooling}

A growing number of low-income countries, including many in Africa, administer surveys to random samples of households, which include standard modules on education, wages, earnings, and other socioeconomic characteristics. These data can be used to estimate the productivity of different groups of workers in the wage labor force and suggest whose children are becoming better educated. These data quantify private investment incentives for expanding different levels of education and for targeting schooling to specific groups in the population. The next step is combining wage benefits of schooling and information on public costs of schooling to approximate social returns. The basic scientific methods for appraising the social externalities from education are not yet in hand.

To assess the limitations of estimated wage functions, which might lead them to be biased or misleading for policy purposes, economic and statistical studies have analyzed household labor force surveys for several decades, and studied specialized samples to control for genetic potential, such as those of identical twins (Schultz, 1988; Card, 1999, 2001). Although this field of research is focused on wage structures in high-income countries, and notably the United States, the underlying issues of statistical bias and measurement error do not seem fundamentally different in the form which they take in low- and high-income countries. Therefore, the methodological and empirical findings from this extensive literature appear relevant to an assessment of the evidence reported in this paper for Africa.

Surveys of the estimates of the returns to schooling provide many references (e.g. Psacharopoulos and Patrinos, 2002; Appleton, 2000), but they generally do not critically distinguish the comparability of various empirical estimates of returns, or the criteria for accepting the validity of an estimate. Specifically, estimates of firm production functions have occupied much attention in 
econometrics, but appear incapable of delivering precise estimates of human capital returns, compared with estimates of individual wage functions for different fixed groups ( i.e. defined by ethnicity or sex) (Mincer, 1974). This does not imply, however, that all wage functions are equally informative, because if they are conditioned on endogenous characteristics of the worker's employment, such as job tenure, occupation, or industry, or on the worker's simultaneous behavior, such as hours worked, migration, or fertility, the estimated effects of schooling they report are likely to be biased from the true private wage return (Schultz, 1988).

In the estimation of production functions at the individual firm or farm level, or at the aggregate level of industries or states, it was recognized in the 1950s that it was important to allow for the variation in the quality of labor in order to understand cross-sectional differences in outputs, or changes over time represented in growth accounting (Griliches, 1970; Jorgenson, 1995). Experimentation with alternative specifications of labor quality, and estimation of flexible forms of production functions, confirmed that years of educational attainment of workers was a reasonable first-approximation for productive "labor quality”(Griliches, 1970). But further refinements have not followed by explicit disaggregation of the labor input into a substantial number of education, age, and sex groups, from which the marginal productivity of different forms of human capital could be confidently inferred. Heterogeneous labor inputs were instead aggregated into efficiency units of “quality adjusted” labor, weighted usually by group wage differentials, and augmented by ad hoc shifters for the proportion of the labor force who were women or in skilled occupations. Perhaps production functions methods could not recover more specifically the labor productivity of heterogeneous workers because of the statistical collinearity among the various productive types of workers, or due to the bias introduced by the endogenous allocation of different (labor) inputs in response to unobserved management ability and technological change. It is not surprising, therefore, that estimates of production functions for firms which employ predominantly nonfamily labor have not contributed importantly to our understanding of the marginal productivity of human capital, or specifically to the rates of return to schooling.

However, better educated farmers or farm managers are observed to be more productive, both because they can produce more in a static setting, and because they enhance the allocative efficiency of production in an dynamic environment where technology and relative prices are changing (Welch, 1970; T.W. Schultz, 1975; Foster and Rosenzweig, 1995). But even at the level of the family farm, conventional quality adjustments of labor inputs do not adequately capture how heterogeneous family labor affects farm and off-farm family production possibilities. 
Other forms of bias may be introduced into the estimation of individual wage functions, if they are estimated from a sample of workers drawn from a single occupation, a sector, or type of firm, which is therefore unrepresentative of the entire population who could be educated, or if the wage function includes as an additional explanatory variable characteristics of the job and employer, which reveal the endogenous quality of the match between worker and job, that depends on unobservables that are correlated with schooling. Employment in a selective formal sector, such as manufacturing firms in Africa, cannot be expected to yield a representative sample of workers, and consequently the observed wage gains associated with schooling conditional on being in such a selective sample are likely to bias downward. ${ }^{5}$ No procedure has been proposed or implemented to correct for this potentially serious bias when reporting manufacturing firm-based estimates of schooling returns (Bigsten, et al. 2000). Nonetheless, across six African countries such manufacturing wage returns tend to increase with the level of schooling, from 2 to 7 percent at the primary school level, to 7-19 percent at the secondary level, and from 21 to 31 percent at the postsecondary level. In addition, these estimates treat job tenure as though it is exogenous, whereas tenure should be treated as endogenous, as shown by Altonji and Shakotko (1987), among others.

Wage differences between workers with various amounts and types of schooling provide a starting point for those who seek policy insights into the private wage returns to schooling. These estimates may then need to be adjusted to take account of social costs and benefits and additional sources of bias. The most salient concern with these direct measures of wage returns to schooling is that other determinants of the wage have not been adequately taken into account, and these "omitted factors" may themselves be plausibly correlated with schooling. Consequently, some of the influence of the omitted factor on wages will be spuriously attributed to schooling. These omitted factors could be related to the productive capacity of the individual worker (such as ability, health, mobility, preferences) or to the process sorting individuals into better paying jobs (i.e., family connections, ethnicity, other market imperfections, such as the political allocation of jobs in public enterprises and in the government's civil service).

There is no entirely satisfactory way to deal with the bias potentially introduced by all such omitted variables, but two empirical strategies warrant discussion. Either the social statistician

\footnotetext{
${ }^{5}$ For example, suppose that unobserved worker ability or motivation is positively related to schooling and to obtaining a (good) job in manufacturing, conditional on schooling. Consequently, the error in the wage function, and the error in the sample selection (or job tenure) equation, will tend to be positively correlated, imparting a downward bias to the estimated effect of schooling on wages, unless the estimates of the wage function are corrected for this selection bias (Heckman., 1979).
} 
attempts to measure the omitted factor and includes it while estimating the wage function, and thereby focuses on the partial association with schooling, conditional on the control variables, or an "instrumental variable" is specified that is associated with schooling but is plausibly assumed to be uncorrelated with the omitted variable. ${ }^{6}$ The original motivation of this literature was to correct for the omitted "ability" and "family socioeconomic status" of the worker which were expected to overstate the wage function returns to schooling. But these expectations have not been confirmed with any consistency by the extensive empirical literature. The first generation of evidence concluded that the magnitude of this total bias in estimated returns was small, probably because the "omitted variable" upward bias was offset by "errors in the measurement" of education, which would bias downward the ordinary least squares estimate of the private wage return to schooling (Card, 1999, 2001).

For example, in the 1970s a school building program in Indonesia focused on the poorer rural areas of the country, which led to substantial increases in educational attainments for persons of school age residing in regions when the new schools were built. These potential beneficiaries of the school building program were observed to be both better educated and better paid when observed in the labor force in the 1990s. The added program expenditure on schools in a region is used by Duflo (2001) as an instrumental variable to explain the added earnings of workers from different regions (i.e. covariance of program expenditures and wages divided by the variance in wages) and which implicitly embodies the intermediate variable of school attainment of the workers (i.e. covariance of program expenditures and schooling divided by the variance in schooling). If these estimates of the program on wages are divided by the estimate of the program effect on schooling, one obtains the instrumental variable (IV) estimate of how much a year of schooling increases a worker's wage. This IV estimate of the private return to schooling is approximately the same as obtained when schooling's effect on wages is estimated using Mincer's direct specification (i.e. covariance of wages and schooling divided by the variance in wages). This school building program shifted outward the supply of schooling, and various specification checks performed by Duflo (2001) confirm that this

\footnotetext{
6

Schooling is mapped onto the instrumental variable in a first-stage analysis, and then this prediction of schooling based on the instrument is used to explain wages in a second-stage analysis, which under specified conditions will be corrected for omitted variable bias and for classical sources of measurement error embodied in the survey variable measuring schooling (Card, 1999). A study of East Africa attempted to hold a worker's achievement score on a standardized test constant, and then evaluate the remaining relationship between schooling and wages (Boissiere, et al, 1985).
} 
program instrument was not correlated with other factors affecting a worker's wage, such as ability, or other social welfare programs, such as those improving sanitation.

Wage patterns in six African countries from 1985 to 1999 are reported in the next section of this paper to assess educational returns. It is ironic that world leaders of higher education are reluctant to consider wage structures for policy purposes (World Bank, 2000), because they think that wage returns to higher education are low. But in these African countries returns to education are substantial, and possibly higher for the young than the old, and higher for those with some postsecondary education. Conversely, other studies document large returns to schooling (e.g. Berthelmey and Bourguignon, 1996) and conclude they are evidence of distorted labor markets and dismiss them as a guide for setting educational priorities.

\section{Wage Differentials by Education in Six African Countries}

Ghana has experienced long swings in its educational investments and economic growth and has released four similar surveys in the last decade. Some features of Ghana can be compared with those prevailing in neighboring Côte d'Ivoire, and to Kenya in East Africa. ${ }^{7}$ Estimates from South Africa are reported by racial groups, which suggests how political restrictions on the supply of education to Africans can raise wage returns. In conclusion, I review new estimates of wage returns to schooling for Nigeria and Burkina Faso, based on a parallel specification of the individual wage function.

Ghana experienced a difficult economic period following its independence in $1957 .{ }^{8}$ Economic growth only stayed up with population growth during the first decade, and from 1965 to 1985 real GDP declined. By contrast, Kenya in this period sustained a growth in per capita GDP of 2 percent per year, while Côte d'Ivoire grew initially at the same rate as its population, and then

7

Other studies of the wage structure in Kenya and the consequences of the divergent paths taken by the educational systems in Kenya and Tanzania relied on data from the 1970s, and often generalized from surveys of manufacturing firms for whom wage workers may not be particularly representative (Knight and Sabot, 1981,1990). The Living Standard Survey of Tanzania collected in 1993 did not include hourly wage data for individuals.

8

In 1957 Ghana and Korea were reckoned to have approximately the same income per capita, comparing local currency GNP by means of foreign exchange rates. Ghana had the highest income level in West Africa at that time, but experienced an economic growth rate thereafter, which was only slightly more rapid than its population growth during the next 25 years. In contrast, Korea grew much faster in the 1960s and thereafter until the financial crisis of 1997 when its income level per capita was about ten-fold greater than Ghana. 
accelerated until the 1980s (World Bank, 1986). By the end of the 1980s, Ghana began to revive, whereas Côte d'Ivoire stagnated, and Kenya expanded rapidly. But in the 1990's the order has reversed; Kenya slowed to an annual growth rate of 2.2 percent, Côte d'Ivoire grew at 3.7 percent, and Ghana at 4.3 percent (World Bank, 2001). Ghana started in the 1950s with wider provision of primary education, while Côte d'Ivoire and Kenya invested more heavily in their public educational system, and caught up to Ghana. Against the backdrop of economic growth and decline in these countries, household surveys can suggest how current wage structures reward those who have acquired more and less schooling.

The average number of years of schooling completed for men and women is plotted as a smoothed five-year moving average by the individual's age in Figures 1 through 6 for Ghana in 1987, Cote d'Ivoire in 1985, Kenya in 1994, South Africa in 1993, Nigeria in 1996-99, and Burkina Faso in 1994, respectively.

In Figure 1 men in Ghana who are age 40 in 1987 (or born in 1947) had attained nearly 8 years of schooling on average, whereas women of the same age had only half as many years of schooling. Men who are age 65 had only 3 years of schooling and women less than 1 year. The lack of growth in educational attainment among younger cohorts in Ghana who were born after 1950 could conceal more recent improvements in average educational levels, if some of the youngest respondents are still in school, and if emigration from Ghana was more likely among the better educated younger birth cohorts. In Ghana the share of GNP devoted to public education was 3.1 percent in 1980, and had increased to 4.7 percent by 1997.

A nationally representative household Ghana Living Standard Survey (GLSS) was collected in 1987/88, 1988/89, and 1991/92 and 1998/99. ${ }^{9}$ Table 2 reports the regression coefficients from each survey where the log of the hourly wage is regressed on the different educational attainment categories for persons age 25 to 54, including as explanatory variables the potential years of postschooling experience and its square and whether the individual resided in a rural area. The educational category excluded from the regression includes persons with no schooling. In 1987, 31 percent of the men had no schooling, and by 1998 only 20 percent were without any formal schooling. Similarly, in 1987, 55 percent of women had not received any school, and this share

9

The GLSS retained a similar questionnaire and comparable sampling methods in the four rounds, although the World Bank participated in the initial two years, and the educational attainment question changed in the last year to emphasize certificates and degrees received rather than the years of schooling completed by level. 
declined to 40 percent in 1998. Relatively few individuals obtained only a secondary school certificate and did not continue to obtain some post-secondary schooling. University degrees are rare, but including also teacher/nurse/technical certificates from post-secondary institutions, the fraction of the population age 25-54 with any higher educational degree is 6.8 percent for males in 1987 and 8.8 percent in 1998, whereas for females the share has remained roughly constant at 2.8 percent.

The private wage returns per year of schooling are estimated in the bottom panels of Table 2, between pairs of educational categories. ${ }^{10}$ Enrollment from primary to middle school yields modest returns, averaging about 4 percent (log points) per year in this period, whereas returns from middle to secondary school are larger, averaging about 11 percent. University four-year degrees earn a return over secondary certificates which averages about 16 percent, but these estimates vary substantially from year to year, probably due to sampling variability given the small number of university graduates observed in the sample in any single survey. The nurse/teacher certificates appear to be well rewarded for a two- or three-year course of study. The inability to assign a particular number of years of study to the heterogeneous degrees called "commercial and vocational” precludes drawing any firm conclusions regarding the estimates of the returns to these varied educational programs, some of which may require of an entering student only a primary school certificate.

Table 3 reports the same specification for the wage function for the first and last year of the Ghana surveys, but the sample is now disaggregated into two age groups to assess how returns are changing over time across birth cohorts. The estimates for returns to university training and postsecondary training tend to be larger for the younger birth cohort than the older birth cohort, suggesting that the balance of the supply versus the demand for better educated workers is becoming more favorable for these younger better-educated workers in Ghana.

In Côte d'Ivoire the expansion of primary and secondary schooling has occurred more recently in the midst of a period of strong economic growth (Figure 2). Cote d'Ivoire spent the largest share of its income on public education in 1980 or 7.2 percent, but this share had fallen by

\footnotetext{
${ }^{10}$ The difference between the log wages for persons in two educational categories in Table 2 is inferred from the difference in the regression coefficients (e.g. in 1987 men with secondary school certificate compared with those with middle school certificates, or 1.135 - .574=.561), which is divided by the number of years of schooling separating the two groups (i.e. 5 years), to obtain the .11 log point private wage return per year of schooling, which is multiplied by 100 to approximate the percentage return to secondary school in Table 2, column 2, next to the bottom row.
} 
1997 to 5.0 percent (World Bank, 2001). As shown in Table 4, the Cote d'Ivoire Living Standard Surveys of 1985/86 and 1986/87 indicate the private wage returns for primary and middle school are roughly 10-12 percent, or somewhat higher than in Ghana. This difference between neighboring countries might be due to the smaller supply of primary graduates in Côte d'Ivoire, or the more rapid national growth of its economy. The returns of secondary over middle school is associated with high returns, 12 to 28 percent, while at the University level returns fluctuate around 10-15 percent. In Côte d'Ivoire the returns beyond secondary school for the younger sample age 25-34 tend to be higher than the returns received by the older sub-sample.

Kenya became independent in 1963 and grew relatively rapidly until the last decade. The expansion of the public school system absorbed 6.5 percent of Kenya's GNP since about 1980, while private and locally funded secondary schools were another avenue to education in Kenya (World Bank, 2001: p.284; Knight and Sabot, 1990). Estimates of wage functions for Kenya (Table 5) are based on the 1994 Welfare Monitoring Survey II. Wage returns are on the order of 9 percent at the middle school level, and they tend to increase for women at secondary level. At the university level the returns are high, and appear to be larger for women than men. The estimated returns are higher for the younger than older cohorts, with the exception of males at the secondary level, suggesting that the supply of primary and post-secondary trained workers has not caught up to the derived demand by 1994. Perhaps in response to the higher returns to women than to men at the secondary and higher educational levels, women in Kenya by 1994 are closing the gender gap in education, and have today attained on average almost as many years of schooling as men. Among earlier generations of Kenyans, age 50-54, women had only a third as many years of schooling as men (Figure 3). This rapid advance in female education relative to male has contributed to the increased rate of migration of women from rural to urban areas, and to the unusually sharp decline in Kenyan child mortality and fertility and population growth.

In 1993 a Project for Statistics on Living Standards and Development collected representative household survey data for South Africa from which Figure 4 is derived. More than three-quarters of the population age 16-65 is black African, 8 percent is of mixed race or "colored," 3 percent is of Asian descent, and 14 percent is white. Table 6 reports the log wage function coefficients, stratified for the two largest groups, Africans and whites. The levels of schooling and wage returns to schooling for the two smaller racial groups are intermediate between those for Africans and whites (Mwabu and Schultz, 2000). The implied private wage returns to higher education are nearly twice as high for Africans as they are for whites, and returns are higher at the post-secondary school level than at the primary or secondary school levels for both race groups and genders. 
One simple explanation for the high returns to secondary and post-secondary education for Africans is that the supply of Africans who have attained these levels of education has been restricted or politically rationed by the previous Apartheid government. For example, two percent of African men age 45 to 65 had any higher education, and 5 percent of African women. Even among the youngest age group, 16 to 29, the fraction of African men and women with any higher education was 5 and 12 percent, respectively. In contrast, 34 percent of white men and 25 percent of white women age 45 to 65 had some higher education, with the fraction increasing somewhat among younger whites. The roughly ten times larger proportion of whites than Africans with higher education is one factor lowering the returns to higher education among the whites compared with the Africans. African wage returns are also higher for the younger groups, suggesting that the imbalance between supply and derived demand was increasing in the last years of the Apartheid regime. The political rationing of advancement of Africans into the higher education system generated both an inequitable distribution of schooling (Figure 4), but also an inefficient allocation of resources from a perspective of maximizing average private returns. This pattern of returns underscores the economic need in South Africa to expand access to higher education for non-whites who were previously inefficiently and inequitably rationed out of the school system, as well as to merge and equalize the quality or public resources spent per student, regardless of race.

A recent analysis of the Nigerian General Household Survey (GHS) from 1996 to 1999 provides parallel estimates of wage returns to schooling for Nigeria (Aromolaran, 2002). Table 7 reports spline (piece-wise linear) estimates of the private hourly wage returns to primary, secondary, and post-secondary schooling for men and women age 15 to 64, also disaggregated into three age groups. In Nigeria the average schooling attained, as reported in this survey sample, increased from 3.07 years for males age 45-64, to 5.75 years for males 25-34, while schooling for females has increased from 1.65 years at age 45-64 to 3.41 years of schooling for age 25-34 (Figure 5). Among wage earners, hourly wage rates increase by about 2.5 and 2.4 percent for each year of primary school, by about 3.9 and 4.4 percent for each year of secondary school, and by 10 and 12 percent per year of post-secondary schooling, for men and women, respectively. ${ }^{11}$

\footnotetext{
${ }^{11}$ Only about nine percent of Nigerian men work for a wage or salary, whereas among women only about three percent are wage earners. Whether the wage structure approximates satisfactorily the productivity of labor in self-employment and family production activities, in which most Nigerians work, is not known. Correcting for the nonrandom process selecting the sample of wage earners may modify the estimated returns of men and women, even though it does not seem to impart a predictable or substantial source of bias in a other studies of low income countries (Schultz, 1995).
} 
Comparing wage returns across birth cohorts, the primary school returns are higher among the older birth cohorts for whom primary schooling was much less common than today, whereas the returns to secondary school are roughly constant across birth cohorts for males, but returns are larger among the younger women age 25-34 than among older women. At the post-secondary school level, returns tend to be higher among the younger cohorts. These estimates for Nigeria suggest a pattern in schooling returns broadly similar to that found in Ghana, where the private wage returns are low at the primary level, and substantial at the post-secondary school level. The absolute gap in years of education between men and women in Nigeria has been relatively stable across age cohorts (Figure 5 and Table 7) in contrast with Kenya where the gender gap has closed.

Finally, trends in educational attainment for Burkina Faso are estimated from a Priority Survey (PS) which is plotted from 1994 in Figure 6. Burkina has the lowest level of income per capita of the countries considered here, and schooling attainment is also the lowest. Among men age 55-59 the mean years of schooling completed is about 0.6 years, and this has increased to 2.4 years in the youngest group, aged 30. Women in Burkina who are age 30 have about half of the schooling of men, or 1.2 years on average, and although female/male fraction was even lower in the past (Kazianga, 2002).

Table 8 reports spline estimates of the primary, secondary and post-secondary schooling private monthly wage returns for men and women age 15 to 65 in Burkina Faso, as inferred from the 1994 and 1998 PS surveys. A year of primary schooling is associated with male monthly wages being 12 percent (log points) higher in 1994 and 9.3 percent higher in 1998, whereas for women these returns are 18 and 16 percent, respectively. At the secondary school level, men's wage returns are higher at 22 and 17 percent in 1994 and 1998, whereas for women they are 22 and 26 percent, respectively. Post-secondary schooling, though uncommon, is significantly associated with 16 and 18 percent returns for men in 1994 and 1998, and with 18 and 13 percent for women, under the working assumption that persons reporting some post-secondary schooling have completed two years of study. Returns are substantial at all schooling levels and higher at the secondary than at the primary level. The percentage wage gains reported per year of schooling completed are generally higher for women than for men in Burkina, although the level of women's wages are lower than men's as they are in all of the other countries, holding their years of education and post-schooling experience constant (Kazianga, 2002).

\section{Empirical Regularities in Schooling Returns Across Six African Countries}

Becker (1964) first noted the empirical tendency for the private internal rates of return to 
education in the United States to decrease at higher levels of education, and this tendency has been frequently discussed as though it is a universal feature of studies of wage returns to education in other countries (Psacharapolos and Woodhall, 1985; Psacharapolos and Patrinos, 2002). ${ }^{12}$ Yet there is nothing in the human capital framework which prescribes this pattern; returns will vary according to supply and demand conditions in the market. Returns to higher education are likely to increase when the supply of better educated workers grows more slowly than the derived demands, due perhaps to skill-biased technical change, specific forms of institutional change (e.g. decline in union membership), or changes in the openness of an economy to international trade and competition (Acemoglu, 2002). The time required for public and private investments in education to expand (or contract) the supply of workers with a specific educational attainment could be a decade or longer, allowing for the emergence of such “disequilibria” or "rents” paid to workers who did not necessarily expect these rents when they made their educational investments.

A preoccupation of economists in the 1990s has been to explain the increase in the wage returns to college-educated workers in the United States (Murphy and Welch, 1992; Katz and Autor, 1999; Acemoglu, 2002). But this pattern of rising returns for post-secondary schooling is now reported in a growing number of middle- and low-income countries, such as Brazil, Chile, Colombia, Mexico, Korea, Taiwan, Indonesia and Thailand, and China (Topel, 1999; Schultz, 2000). The evidence from recent representative surveys in Africa, which was presented below in section 6, confirms the same regularity, and should be taken into account by policy makers as they consider educational priorities in Africa. ${ }^{13}$

If private returns to schooling increase at more advanced levels of education, poorer families who are on average educating their children at the primary school level will face low returns, while richer families who are on average educating their children to secondary or post-secondary school level face much higher returns. Thus, all families may invest efficiently in their children's human capital to maximize their family's wealth, and not be subject to borrowing constraints, and yet the

\footnotetext{
12 Becker (1964; p.127) concluded from his analysis of U.S.1940 census data that private returns for white males were about 18 percent in high school (secondary), but declined to about 10 percent at college level. In the second edition of his Human Capital he includes a discussion of mechanisms (i.e. ability of student and borrowing costs) which would allow the family supply of investments in schooling of their children to differ, despite the hypothesized diminishing returns to schooling reflected in the derived demands for workers with different levels of schooling (1975: 94-144). Having the returns to schooling increase with higher levels of schooling adds an additional factor contributing to inequality in schooling investments across individuals.

${ }^{13}$ Note the same pattern in returns is observed within the Manufacturing sectors in six African countries reported by Bigsten, et al.(2000), although the specifications adopted in this study is not comparable to the one adopted in this study.
} 
poor are motivated to invest less per child than the rich. Families may also be inclined concentrate their schooling investments in their most promising children who are more likely to reach a higher level of education for which the returns are expected to be higher. Inequality in education and earnings may then more likely to increase overtime both between families and within families, which differs from the setting described by Becker (1964) in the 1940 US Census in which the marginal returns to schooling decrease at more advanced levels of schooling.

What policies can help the poor enroll their children in basic schooling until private returns increase enough to provide them with the incentive to continue marginal investments in more schooling? The challenge is to design these policies to promote both an efficient composition of schooling without adding to future inequalities in society.

\section{Who Benefits from Subsidized Education}

The distribution of educational opportunity across persons in Africa is currently unequal. Cross tabulations of information available from the Living Standard Surveys collected in Ghana and Côte d'Ivoire illustrates this inequality which represents the lack of social mobility across generations. The surveys ask for the education of the mother and father of all household members. I consider here how the "likelihood that a person receives some higher education" is associated with the schooling of his or her parents. The likelihood is calculated for all persons in these surveys, and thus omits from a birth cohort only those who emigrated or died before the survey. Table 9 shows that 1.8 percent of the men age 55 or over in Ghana attended some higher education, whereas that fraction increased more than four fold to 8.8 percent among those aged 35 to 44, and then possibly declined to 6.7 percent in the youngest age group 25 to 34. Women in Ghana also experienced a large increase in their higher education, but their likelihood of attending higher education was only about a quarter that of men. The prominent gender disparity in higher education in many African countries does not occur in South Africa (Figures 1-6).

Among men in Ghana age 55 and over, those whose father had some secondary schooling had a 40 percent chance of attending higher education, 22 times the national average, and 33 times that of a male whose father had not attended school (Table 9). Those older men with a mother who had some secondary school attended higher education 67 times more frequently than those with a mother who had no schooling. These indications of substantial inter-generational inequality of educational immobility diminished for the younger men, as education became more widespread. Among men age 25 to 34, their likelihood of continuing to higher education was about 4 times greater for persons with a father with some secondary school than for those with a father who had no schooling, and 7 time greater if his mother had this relative advantage in her schooling. 
Until the 1970's, the educational system reached a smaller fraction of the population in Côte d'Ivoire than in Ghana, but thereafter higher education was obtained by nearly twice the share of males in Côte d'Ivoire as in Ghana, or 11 percent of those age 25-34, while 2.8 percent of females of this age had obtained any higher education. ${ }^{14}$ Among men age 45-54, the likelihood of attending higher education in Côte d'Ivoire is 25 times larger if their father had some secondary schooling than if his father had no schooling, and 50 times larger if their mother had this same relative educational attainment. These odds ratios of receiving higher education conditional on a person's father's education declined in Côte d'Ivoire to 3.5 for males age 25-34, and based on his mother's education they declined to 7.4

The low level of inter-generational educational mobility reported here is consistent with the observations of others (Psacharapoulos and Woodhall, 1985; King, 1997; Colclough, 1997; Kimalu. et al., 2001). Higher education, which is predominantly public in Africa, has absorbed relatively large public subsidies per student year, often without charging any student fees, and in some cases, such as Côte d'Ivoire, academically qualifying student are given living stipends, regardless of financial need. The resulting large public transfers made to students enrolled in higher education benefit predominantly those families who were relatively well educated in the past. According to the wage functions reported earlier, these well-educated parents receive, on average, relatively high wages, and their children will be disproportionately at the top of the income distribution in the next generation. Without efforts to help the poor qualify for, and to enroll in, higher education, the maintenance of current policies will contribute to sustaining the substantial economic inequality present in Africa.

What are the policy alternatives, which might reduce these undesirable distributional consequences of the current African system of education? The challenge is to find a self-sustaining source of revenues on which to build an expansion of higher education, while at the same time to reduce the concentration of "rents" generated by the current system of higher education for the children of the upper classes.

\section{Policies to Improve the Distribution of Public Subsidies for Education}

\footnotetext{
${ }^{14}$ These differences between Ghana and Côte d'Ivoire may be affected by emigration, and thus may not reflect accurately the levels of educational attainment achieved by a sequence of birth cohorts in the two countries. It is likely that a larger fraction of higher educated individuals, especially doctors and engineers, from Ghana left the country during the 1960s and 1970s when growth was much lower in Ghana than Côte d'Ivoire.
} 
Changing the personal distribution of benefits of higher education can be accomplished by a variety of pricing, transfer, and regulatory policies, and perhaps by changing the mix and location of educational institutions in Africa. Student loans, quotas, and targeted subsidies are all conventional methods to deal with the distributional problem described here, and they have been tried in different contexts with mixed success (Albrecht and Ziderman, 1991; Johnstone, 1992; Colclough, 1997; Tilak, 1997). Which of these approaches hold the greatest promise for Africa?

Given the survey evidence that private wage returns to higher education are substantial, why do poor families not invest more in the schooling of their children? One hypothesis is that the poor family and student are credit constrained, at least when they want to invest in human capital, because human capital does not offer lenders a recoverable form of collateral in case of default, such as land for the farmer who borrows (Jacoby and Skoufias, 1999). One solution proposed to this problem is to offer student loans, which the students could repay from their enhanced earnings as adults. A central student loan facility could hope to monitor the earnings of most workers with a higher education, since they predominantly work in the modern sector. By pooling large numbers of loans to students with different abilities, specialties, and working in distinct labor markets, such a facility should be able to reduce the risk on its overall portfolio and thereby reduce the interest rates it must charge to self finance loans. This approach was first adopted at some private universities in highincome countries, and then extended nationally by governments to students from relatively poor families to finance a fraction of the actual costs of higher education. The U.S. government has been able to require income tax forms to validate parent income and student means of support, and thereby minimize the opportunities for fraudulent claims of financial need or subsequent default (Nerlove, 1975). Yet evaluations of a variety of student loan programs in low-income countries conclude they have had serious problems, with sufficiently high default rates to prevent them from becoming self sustaining, while the cost of administration represents a large fraction of total program costs (Woodhall, 1992). Kenya and Venezuela are cited as examples where repayment rates were sufficiently low that it would have been cheaper for the government to have converted the loans to outright scholarships (Colclough, 1997; p.77). Moreover, if students with higher education become highly indebted to a State loan program, this might encourage emigration as a means to escape the burden of repayment, exacerbating the growing problem of brain drain. Pressure to institute restrictions on immigration of higher educated citizens could then follow (Bhagwati and Partington, 1967).

Quotas have been used by India to achieve more representation in higher education by persons from lower castes and scheduled tribes and to increase the fraction of women in political 
offices (Chattopadhay and Duflo, 2001). Although admission quotas may achieve a redistribution of the benefits of higher education, they are likely to also create a lower quality of schooling for the groups assigned minimum quotas. If the quota is not based on a readily monitored characteristic such as sex, caste, or race, how would it be administered? Ethnic and language groups might be identified which had below-average educational attainment, according to a population census or nationally representative household survey, and individuals from these disadvantaged groups could then be assigned a compensating upward adjustment in their rankings for fellowships and for admission into institutions of higher education. Although such a policy might have appeal for its transparency, it could also have undesirable political consequences in a country where ethnic conflicts are already a serious source of social friction.

What would constitute a satisfactory index of "economic need" on which to target transfers in order to redistribute the benefits of higher education? What readily verified information could be used to direct educational subsidies to the educationally disadvantaged, which would not encourage counterproductive forms of behavior or misrepresentation? The survey data presented earlier for Ghana and Côte d'Ivoire suggest that parent education would be one such basis for identifying those differentially represented among those receiving higher education. Awarding an educational subsidy on the basis of your parent's educational disadvantage would not discourage productive effect on effort or labor supply or market earnings, as would means-tested transfer, and would presumably be easier to administer and monitor by a government auditor than would the current income or wealth of the parents.

Geographical targeting should also be simpler to administer and in some countries it would be relatively efficient. The income and education gaps between rural and urban populations are generally larger in low-income countries than in high-income countries where there is greater labor mobility. Tables 2 through 6 illustrate that wages are substantially lower in rural areas, even after controlling for the worker's schooling, age, and sex: wage rates are between 30 and 43 percent lower in Ghana; 38 and 75 percent lower in Côte d’Ivoire; 45 to 61 percent lower in Kenya; and 30 to 33 percent lower for Africans in South Africa, but rural residence is not reported in the Nigerian survey, and this distinction is oddly insignificant in the Burkina Faso survey. ${ }^{15}$ Per capita household

15

The coefficient on rural residence in the wage functions reported in Tables 2-6 and 8 is converted to a wage differential by exponentiating the coefficient and subtracting it from 1.0. This represents how large a proportion the rural wage is of the urban wage. For example, for Kenyan males age 25-34 the rural wage is 55 percent of the urban, i.e., . $55=\exp (-.603)$ or .45 below urban levels. 
expenditures could be estimated from a national household survey to target scholarships to children from regions with more widespread poverty.

Between a fourth and a third of the variation in educational attainments across individuals in Ghana and Côte d'Ivoire can be accounted for by a three-variable geographic distinction (rural/capital city/other urban), parent schooling, and age, as illustrated by the regressions summarized in Table 10. In Côte d'Ivoire the average education of a men in Abidjan is 4 years greater than in the rural areas, when the national average for males age 25 to 54 is 3.8 years of schooling. A man with a father who completed only 8 years of education versus a father with no schooling is associated with a four years advantage in schooling (i.e., . $521 * 8=4.2$ ). An educational subsidy could be targeted to children from (poor) rural areas whose parents have the least education following a simple estimable relationship as reported in Table 10. These subsidies could be financed by increasing tuitions for students currently enrolled in public higher education whose parents reside in urban areas and have above average levels of education. As discussed in the next section, increased student fees could not only finance the personal redistribution of the benefits of higher education toward poorer families, it could improve the governance and operation of higher education.

In the last decade, a variety of low-income countries have implemented human capital incentive programs to encourage household demand for more schooling, and these programs could be adapted to African circumstances. Bangladesh introduced a secondary school scholarship program for girls, which placed the scholarship in a bank account for the girl, contingent on her not marrying before age 18. Other government programs are restricted to poor families, transferred food allotments (wheat) to each family if their children attend school 85 percent of the days in the school year (Arends-Kuenning and Amin, 2000). In Mexico, transfers to the rural poor were started in the fall of 1998 within a program called "Progresa" and by the end of 2000 three million families residing in small, poor, villages were eligible to receive school and food subsidies. The program seeks to increase the school enrollment of children from poor families by giving cash grants to mothers whose children are enrolled in grades three through nine and attend 85 percent of the time. The size of the transfer payment increases with the child's grade level to compensate the family approximately for what a child could earn by working if they did not go to school. The Progresa program transfers raised on average the consumption levels in eligible poor households by about one-fifth, improved their nutrition, and increased the expected schooling of their children from 6 to 7 years (Schultz, 2001). Three States in Brazil have experimented for several years with school enrollment bonuses for poor families, and the Federal government of Brazil enacted legislation in 2001 to extend these programs to the poor throughout the country in 2002 (Sedlacek, 2001). These means-based 
educational subsidy programs require methodical planning and careful monitoring to achieve their objectives of redistributing human capital, but they hold the promise of alleviating poverty while simultaneously encouraging productive investments among the poor in the nutrition, health and schooling of their children. These demand stimulating school subsidy programs may turn out to be more cost-effective in reaching disadvantaged children than traditional public expenditure programs, which add to the public supply of services, by building more schools (health clinics), or increasing the salary levels of existing teachers (nurses), or expending more on school (clinic) quality (Schultz, 2001).

African nations might experiment in the design of education subsidy programs targeted to the children of the poor. These social welfare experiments must be evaluated rigorously to access their consequences and provide the feedback to improve their design. Experimentation with such programs in Africa should be undertaken with care, recognizing differences in local institutions and how programs are implemented from country to country. These demand subsidies to households for public education programs could help Africa avoid creating the patterns of ingrained economic inequality that have a grip on Latin America. What role could private education play in this reform process?

\section{Private and Public Education, Governance, and Accountability}

Private educational institutions may help produce the skills that the wage functions reported in Section 6 indicate are economically most scarce in Africa today. Given the high cost of expanding public higher education, governments should be reluctant to stand in the way of private firms, though some forms of regulation of higher education may be justified. ${ }^{16}$ The private sector may find some programs of higher education more suitable for specialization than others. Experience in the United States has led to the view that vocational training, apprenticeships, and some professional programs may be more successful if organized in the private sector than in the public sector. This may be because demands for specific types of vocational knowledge change rapidly and private groups appear to be more flexible and responsive to such evolving labor market derived demands than are public agencies. In particular, the public sector may be restricted by civil service regulations and

\footnotetext{
${ }^{16}$ Ghana has encouraged the establishment of private universities and is experimenting with the capacity of private universities to attract emigrants back to the country to teach in these new institutions, after their training and experiences abroad. Kenya has allowed private universities to fill some of the excess demands for higher education which the public sector cannot accommodate. Uganda has allowed university fees to become a major source of funding to expand the provision of higher education and reduce the public subsidies for this sector, implementing some of the measures discussed in section 8.
} 
personnel policies, and collective bargaining agreements, which limit its capacity to hire, advance, and fire employees as new fields of knowledge and technologies grow and decline. This flexibility may be especially valuable to deliver training programs based on new educational technologies, such as those fostered by the Internet and allied to distance learning.

Private sector training organizations will need to charge students the full costs of training, thereby setting a competitive market price for training which should help the public sector adjust its own structure of fees and tuition toward market-clearing prices. Any excess demand for admission into the subsidized public sector institutions could then be diverted to private institutions for which the private costs would probably be higher than in the public sector. Although this development of private training organizations may create a lower-quality tier of private schools catering to the upper middle classes, it should help to create a constituency for more competitive tuitions and fees in the public sector. Examples might be found in terms of business and accounting schools, secretarial training, and technical skills relevant to the installation and use of new information technologies, where the government might retain a role of administering proficiency examinations to set standards on the quality of training individuals receive in the private and public sectors. Public sector resources may be reallocated toward areas of academic and professional training which require more infrastructure. These forms of specialization between private and public institutions could lead to expanding public programs in the physical and biological sciences and engineering, preserving core studies in mathematics and statistics, social sciences and the key fields of the humanities, justified in part by more self-financing enrollments. With the increase in fees, students would also have stronger incentives to complete their studies more quickly. Independently administered exams for professional competency could encourage a desirable competition between private and public training institutions.

Those professions which are employed mostly by the public sector, such as teachers, nurses, and agricultural extension workers, might be justifiably emphasized in the mix of programs in the public sector higher educational system, because increasing the number and quality of graduates from these programs should benefit directly the public sector. Increasing the supply of these professionals should contribute to reducing the wage rates which the public sector will need to pay in the future for its personnel (Schultz, 1987). This argument for public training of teachers, nurses, etc. may be stronger if the labor market institutions surrounding public employment in a country are competitive and the public sector regularly evaluates its employees and only renews the contracts of those employees who are doing an satisfactory job. On the other hand, if these public sector teaching, nursing, and extension appointments are lifetime sinecures, and are not subject to 
monitoring and work incentives, the public may not gain from increasing their supplies. Instead, the consequence may be smaller class sizes in education, which may be primarily an amenity valued by teachers and not an efficient use of public educational resources (e.g. Kimalu, et al., 2001).

Increasing emigration to other countries in the region or to high-income countries signals that individuals in a particular career or professional occupation are domestically in excess supply in the national economy, relative to demand, or that career advancement is regulated by bureaucratic rules and seniority, which discourage entry by the more ambitious and able workers. Before increasing the public training in such areas of "brain drain," a careful review of the conditions of employment and training in the country may identify other constraints and regulations which might be modified to make domestic employment in the field more attractive and competitive compared with those jobs available in other countries. Clearly, some of the skills needed are those for which there are good jobs abroad, and holding on to top scientists, doctors, and engineers will be perennial problem for low-income countries. Institutions of higher education have a major challenge to restructure their hiring and advancement policies to reward performance and compete for a suitable number of the best faculty in critical fields. As long as public institutions of higher education are regulated by civil servant pay scales and hiring regulations, these institutions will be at a serious disadvantage in getting and keeping the most talented or the hardest-working faculty.

This raises the complex issue of administration and governance of higher educational institutions: how to make them responsible at one level to the government and to the public through transparent financial and output records, and yet introduce decentralized budgeting, personnel management practices, and incentives to motivate individuals to perform their individual roles and to cooperate in the joint tasks required of a first-rate system of higher education. Governing boards of higher educational institutions should be insulated from government interventions, but they must nonetheless be responsible to the public, which requires the development of special institutions adapted to higher education as well as local conditions. Transparency of finances is essential, but to gain control of priority setting, these institutions should decide how to allocate their own revenue fees, subject to periodic public audits and review.

There has been criticism for many years of setting fees for public higher education too low, which leads to "excess demand" for university admissions, which tends to favor the upper middleincome classes. ${ }^{17}$ Political pressures from the groups in Africa which are favored by the current

\footnotetext{
${ }^{17}$ Korea, for example is reported to spend 3.5 percent of its GNP on primary and secondary education, striving to equalize its quality across regions, while parents spend almost as much on
} 
system of "free” universities lobby against raising university fees to recover from students a more equitable share of the public costs of higher education. As a consequence, university faculty are confronted with growing class sizes, decreasing support for training infrastructure such as laboratories, computers, and libraries, as well as in many settings decreasing real salaries. Faculty may hold multiple teaching positions to maintain their standard of living, but this may limit their capacity to also undertake research which could update their teaching. Empowering professional societies or teacher unions may strengthen the bargaining position of teachers with regard to their conditions of work and compensation, but could also weaken competitive pressures on faculty to be monitored and rewarded accordingly to the quality of their research and teaching. There are good reasons for insulating university fiscal policy, administration, and curriculum design from political pressures, and placing them under greater faculty control. These issues of governance in higher education are as salient in low-income countries as they are in high-income countries, but higher educational institutions in Africa are in particular need of securing more economic independence of the government, and self-financing from tuitions could represent a significant first step in that direction.

The revenues from educational fees may be used to create new programs, to close unsuccessful ones, to strengthen selectively old ones, to allocate funds for incentive pay and performance standards among faculty. The use of such new funds in higher education could begin to remedy many of the entrenched problems that have weakened some outstanding universities in Africa. The ability to allocate new user fees would give the higher educational governing boards a flexibility to respond to organizational problems that may be difficult to otherwise reform, and to initiate new activities for which the social returns are arguably high. Decentralization in resource allocation and decision-making should be encouraged, down to the Department level or the Research unit, with the governing board specifying and monitoring the desired outcomes, including degrees awarded, enrollments and quality of instruction. Faculty involvement in the selection of their peers to term-positions in University management might also maintain professional standards and reduce the extent of corruption.

Another of the long-standing organizational challenges facing higher education is to orient its research and training capacity to problems that have local social and economic importance and have the promise of generating local social benefits. One linkage that is often difficult to achieve is that

tutoring to purchase an advantage for their children to gain admission to the prestigious public universities which are "free" (Kim and Lee, 2001). 
between private industry and university researchers which typically involves the practical application of new knowledge. The industrial firm wants to control the knowledge and innovations it produces by patents and the like, whereas the university faculty wants to publish their research findings to add to the base of knowledge which is recognized by their scientific peers. These conflicting incentive structures of industry and academia also arise in high-income countries, and low-income countries should look for way to create an environment where private firms and university researchers can pool resources in well defined situations where both sides stand to benefit and where public interests are served in the exchange.

Creating an intermediate level of research center, which could be allied to a university but financially semi-independent, might provide a institutional arrangement for rewarding researchoriented faculty with a supplemental salary, research laboratories, and justified research expenses, while leaving intact the more uniform compensation scales for faculty who perform satisfactorily their teaching duties. Some universities in the United States, for example, have separate, yet coordinated, institutions which help in the recruitment of outstanding scientists and scholars, offering a supplemental salary to research faculty on competitively renewable terms of appointment. If universities are not encouraged to create such independent research centers, they may develop outside of the university system, in what some countries call "academies of science research institutions”, and these better paying centers will attract away some of the more creative scientists from the task of training the next generation.

\section{How does HIV/AIDS Affect Returns to Education in Africa?}

The repercussions of the HIV/AIDS epidemic in Africa are poorly understood. An empirical assessment of policy choices to deal with this human tragedy involves evaluating how to invest economic resource today to enhance the productive capacity of individuals over their future lifetimes, and should be naturally analyzed within the human capital framework. Individuals make behavioral choices based on limited knowledge as to how their behavior affects the likelihood that they will become infected and the consequences of such an infection on themselves and others about whom they care. The human capital analytical framework is well designed to consider complex choices individuals make, which involve current costs and have the promise of enhancing the lifetime consumption opportunities for themselves and others in their nuclear and extended families. Therefore, human resource economics should be in the forefront, defining the data and directing the analysis society needs to optimize public sector investments in response to the epidemic, and to improve understanding of how behavior affects lives.

HIV/AIDS differs from most infectious and communicable diseases, first because of its long 
gestation period, second its link to sensitive areas of sexual behavior, and third its incidence and mortality differentials by age and by socioeconomic class. The onset of the infection and the outward manifestations of the disease are separated by about a decade, and during most of this latent period of HIV infection the disease can be unknowingly transmitted by sexual intercourse, or blood contact, as can occur by sharing needles for the injection of drugs or transfusions.

Because the mortality caused by HIV/AIDS occurs frequently among adults in the middle of their working years, aged 30-45, this disease imposes a heavy economic burden on families and society, compared with other sources of mortality. In contrast, to most infectious and degenerative diseases, individuals who die of AIDS tend to be near their peak lifetime productivity, and they might otherwise expect to enjoy many years of productive work and thereby provide support and care for others, including their dependent children.

One implication of these characteristics of the AIDS epidemic is that it reduces the private and public incentives to invest in education. But other developments may mitigate some of these well-known effects of AIDS on human capital formation. It is said that each year several percent of the schoolteachers are dying of AIDS in severely affected sub-Saharan African countries, such as Malawi (Kelly, 2001). These circumstances will contribute to a growing scarcity of teachers, and in order to attract suitable replacements for the teachers who die, governments will need to pay teachers higher salaries. The decrease in expected survival of adults would thus diminish the private demand for schooling, whereas the resulting rise in the salaries of teachers would increase the incentive for youth to continue their education in order to become a teacher. Firms may also have a diminished incentive to subsidize on-the-job training of its workers (i.e. firm-specific training), because fewer of these workers are likely to survive to repay the firm with their enhanced productivity. On the other hand, firms may expect to encounter rising costs in the future to replace workers who have more onthe-job training

How will new information about the disease diffuse through the population, and what will be the behavioral consequences of the availability of tests to determine illness status and antiretroviral drugs to suppress the virus for mother to child transmission and for others. Who will be the first to adopt new patterns of behavior to reduce transmission risks with the new information and options? ${ }^{18}$

18

Representative panel surveys are needed which might document how behavior changes when "a priori” expectations of infection status are replaced by test results. How do the resulting modifications in prior beliefs regarding infection status influence transmission-related behavior? (Boozer and Philipson, 2000). The changes in behavior that occurs because test results are provided should depend on how different the a priori expectation of the individual's infection status are from the actual test result. For example, sex workers who 
De Walque (2002) presents estimates of how the gradient of HIV infection with respect to schooling has changed for a rural Uganda population followed over time. The partial correlation of education with the incidence of HIV is initially in 1989 positive, and has become significantly negative a decade later in 2000. If this change in the educational gradient in the rate of new infection is a general feature of the epidemic in Africa, as improved information about the disease becomes available, and the observed association between education and infection can be interpreted as causal, then education may both raise the labor productivity of surviving individuals and increase life expectancy by reducing HIV infection, and thereby would be expected to increase the returns to schooling.

AIDS prevention programs could involve two components, the first providing information about the disease and behavioral changes that can reduce the risk of infection or transmission, and the second subsidized diagnostic testing for HIV infection and confidential consultation with the tested individuals on how to interpret and react to their own test. In the Uganda panel study mentioned earlier, de Walque (2002) reports that the probability that a condom was used in the last sexual intercourse increased over time more rapidly for educated than for less educated individuals in the panel, especially for women, suggesting one behavioral mechanism which could account for the change in the education gradient in infection rates. The speed at which these changes in HIV/AIDS related behavior, infection rates, and prevalence rates occur is likely to depend on regional mobility of the population, initial patterns of sexual behavior, among many other factors, and how these factors differ across socioeconomic strata of each society (Ainsworth and Over, 1997; Kelly, 2001).

Unless negative externalities can be confidently attributed to the dissemination of information, both with regard to the characteristics of a communicable disease and the individuals own infection status, information should be provided to as many people as possible. Otherwise, better-educated and richer individuals will have an advantage due to their knowledge about the disease, and have themselves privately tested to derive whatever welfare advantage from modifying their behavior and seeking drugs. Unless a strong case can be made for withholding information

think they have contracted HIV/AIDS may have more reason to change their behavior if they learn that they are not currently infected, and may thus change their occupation to reduce their exposure to risks of infection in the future. How behavior changes in response to testing and counseling depends on a subtle balancing of altruistic and selfish motivations, and the alternative income opportunities individuals have to obtain support for themselves and their families while reducing their exposure to risks. These are complex choices for which empirical analysis is essential, because theory (or the intuition of physicians, policy makers or economic theorists) is not a sufficiently reliable basis for policy choices. 
about AIDS from private individuals, testing should be encouraged, and public subsidies should be provided to spread the information from these test to all those who are tested.

Individuals may treat persons suspected of being infected by HIV/AIDS in a different manner (i.e. stigma) than they do those who they think are uninfected. Isolation from social networks due to being classified as probably HIV/AIDS-positive may not only cause psychological stress for the shunned individual, it may weaken family and neighborhood institutions which otherwise provide many poor people with the means to protect themselves and their families against the losses associated with chronic health crises. It may lead to the exclusion from school of orphaned children or children of sick parents (Gertler, et al., 2002). Providing orphans with legal rights to attend school system, could reduce the likelihood that the next generation will fall into poverty (Ainsworth and Filmer, 2002).

Without knowledge of who is sick, and how behavior changes when individuals become HIV positive, and then manifestly ill with AIDS, and related opportunistic diseases (such as TB and pneumonia), the direct consequences of the epidemic remain difficult to appraise. Unless variation in access to prevention and treatment programs can be related across residential areas and over time to incidence and prevalence rates, statistical assessments of the impact of program interventions will remain highly uncertain and public policy will be left to the intuition of political leaders.

\section{Conclusions, Policy Implications and Research Priorities}

There are three interrelated issues in the design of an efficient and equitable educational system. First, the productivity of similar workers with different levels of schooling must be assessed. Second, the personal distribution of the benefits of an educational program should not add to economic inequalities, and if possible reduce them. Third, the specified levels of education should be produced at least private and public cost.

This paper has dealt primarily with the first question of how the private productivity of wage workers differs according to their education, as observed in recent household sample surveys from six African countries. The second question is inescapable because the highest private returns to education are associated with post-secondary schooling, for which the benefits are most unequally distributed. The third question has been neglected in this paper. It involves the design of public policy interventions in order to minimize the public and private costs of educational outcomes: (1) increasing the years of schooling youth complete, or (2) increasing the labor market productivity of a worker with an additional year of schooling, or (3) enhancing other welfare benefits enjoyed by students. These efforts to improve the operational efficiency of the educational system are commonly evaluated by means of retrospective analysis of program outcomes, such as student 
enrollments, matriculations, and test performance. The units of analysis may be administrative regions, communities, schools or even classrooms, for which the level and variety of school inputs or administrative structure of incentives vary. But such variation in school inputs and organization rarely occurs independently of other confounding factors which are also likely to affect school outcomes. The underlying conditions which give rise to the variation in schools will tend to be correlated with student family background, regional population characteristics, and other school attributes, all of which influence school outcomes. Therefore retrospective relationships between measured school inputs and outcomes, often called school production functions, can and do produce misleading estimates of the consequences of policy changes (Kremer, 2000). This problem is illustrated in Kenya by Glevve and Kremer (forthcoming), where an intervention providing promising school inputs was evaluated retrospectively, and then evaluated prospectively by systematically administering the input to a random set of schools and also studying the same educational outcomes in a random set of "control" schools. The retrospective study concluded the inputs were cost effective, and the randomized social experiment could find no significant effect of the inputs on school outcomes. The added cost and time of prospective randomized program evaluation may be warranted in setting educational policies, in order to be confident that confounding factors do not bias retrospective evaluation studies.

Analysis of the economic productivity of employees who are trained by the educational system and continue to work in Africa is one way to infer the contribution of education to the economy and to the development of the continent. A comprehensive evaluation of education would require an assessment of both the private wage returns to schooling, which are essential to motivate families to educate their children, and the public accounts of benefits and net public expenditures on schooling, which together with the private returns define the social returns to education (Table 1). The equity of public subsidies for higher education is a disquieting problem for Africa, because higher education in Africa absorbs relatively large public subsidies per student, and benefits accrue disproportionately to the children of relatively well-off families. Can expansion of higher education in Africa be restructured to return more of the benefits of higher education to relatively poor families? The standard policies which might accomplish this redirection of benefits of higher education to the poor involves having the rich and middle classes paying more of the costs of the higher education, which they currently consume, and thereby reduce the subsidies per student. The additional tuitions and educational fees thus collected could make a substantial difference by augmenting the funds available for fellowships for the poor. 
In this paper, I have assembled empirical evidence from household surveys collected from 1985 to 1999 in six African countries --- Ghana, Côte d’Ivoire, Kenya and South Africa, Nigeria and Burkina Faso. Workers are receiving higher wages to compensate them for having enrolled in education, and the wage gains associated with each year of education completed range from about 5 to 20 percent, if we exclude the extraordinary wage returns of Africans in South Africa. The private rates of return to higher education are relatively attractive by world standards, 10 - 15 percent, suggesting that private families and individuals in Africa currently have a strong financial incentive to acquire more higher education. But can the poor attain these substantial returns only if they first complete the primary level for which returns appear to be modest, on the order of 3-10 percent?

If there are benefits to education, which accrue to members of society other than the students and their families, methods should be developed to evaluate these social external returns. This task is daunting and controversial, but a start should be made to extend the analyses reported here of the private wage returns to include first the public costs of providing the education, and second defensible estimates of the value of social externalities generated by education for the wider society. It is not satisfactory to dismiss private wage returns to schooling in a low-income country because they are incomplete or imperfect, which they certainly are. The claims on public revenues for education should be based on quantifiable cost-effectiveness accounting, going forward.

Although in some African countries, such as Kenya, women have made strides in general education, the gender gap in schooling remains large in Côte d'Ivoire, Ghana, Nigeria and Burkina Faso. By contrast, the gender gap in education is not evident in South Africa. Since there are persuasive reasons to think that educating more women will improve the health and schooling of their children, as well as reduce fertility and slow population growth, such spillover effects of female education can be interpreted as a social externality justifying an extra social subsidy for female education. But these arguments for governments investing more in women's education are better documented at the basic primary and secondary school levels than they are for higher education (Schultz, 2002).

The major drawback of higher education in Africa is that it benefits children who are mostly from upper economic classes, living in urban areas, whose parents are well educated relative to the standards of their generation. In other words, higher education is heavily subsidized by government, and financially benefits predominantly the upper classes, and thus increases future economic inequalities in Africa. These inter-generational patterns of low educational mobility were illustrated in two African countries in Table 9. Nonetheless, comparisons of Africa with other low-income 
regions, such as those in Latin America or South Asia, may indicate that Africa is no more unequal in its distribution of educational benefits than elsewhere (King, 1997).

Unless a mechanism is found for improving the personal distribution of the benefits of higher education, it is not clear on what basis international development agencies, private foundations, or other non-government organizations can justify further expansion of higher education in Africa. Governments in the region do not appear to assign a high priority to improving the quality of higher education, or encouraging higher education to evolve toward a self-governing status. Primary and secondary levels of education, programs favoring women's education, programs in preventive and public health such as would slow the spread of AIDS, would all seem to exhibit a stronger claim on public funding in Africa. This is because the benefits from these alternative social welfare programs are more widely distributed across all classes in the society than is currently the case with higher education. 
Table 1

Benefits and Costs of Schooling Which Determine Private, Public and Social Returns to Schooling

\begin{tabular}{|c|c|c|c|}
\hline $\begin{array}{l}\text { Who Benefits and } \\
\text { Pays for Schooling? }\end{array}$ & $\begin{array}{l}\text { Benefits Caused by } \\
\text { Schooling }\end{array}$ & $\begin{array}{l}\text { Costs Incurred to } \\
\text { Produce Schooling }\end{array}$ & $\begin{array}{l}\text { Net Rate of Return to } \\
\text { Schooling Over a } \\
\text { Lifetime }\end{array}$ \\
\hline $\begin{array}{l}1 . \\
\text { Private incentives for } \\
\text { student-family to } \\
\text { enroll in school }\end{array}$ & $\begin{array}{l}1 \mathrm{~A} . \\
\text { Increased wage } \\
\text { opportunities after } \\
\text { taxes } \\
\text { Increased } \\
\text { consumer benefits }\end{array}$ & $\begin{array}{l}\text { 1B. } \\
\text { Value of student's } \\
\text { time while going to } \\
\text { school } \\
\text { Direct financial } \\
\text { expenses, fees, etc. }\end{array}$ & $\begin{array}{l}\text { 1C. } \\
\text { Private rate of return } \\
\text { that equalizes the } \\
\text { present discounted } \\
\text { value of private } \\
\text { benefits and costs }\end{array}$ \\
\hline $\begin{array}{l}2 . \\
\text { Public sector } \\
\text { accounts of } \\
\text { schooling beyond the } \\
\text { family }\end{array}$ & $\begin{array}{l}2 A . \\
\text { Social externalities } \\
\text { e.g. reduced } \\
\text { exposure to disease } \\
\text { and crime }\end{array}$ & $\begin{array}{l}\text { 2B. } \\
\text { Public expenditures } \\
\text { on education minus } \\
\text { fees and taxes paid } \\
\text { over a lifetime }\end{array}$ & $\begin{array}{l}2 \mathrm{C} \text {. } \\
\text { Public sector rate of } \\
\text { return }\end{array}$ \\
\hline $\begin{array}{l}3 . \\
\text { Social accounts }\end{array}$ & $\begin{array}{l}3 \mathrm{~A} . \\
\text { Private and public } \\
\text { benefits }\end{array}$ & $\begin{array}{l}3 B \text {. } \\
\text { Private and public } \\
\text { costs }\end{array}$ & $\begin{array}{l}3 \mathrm{C} \text {. } \\
\text { Social rate of return } \\
\text { that equalizes the } \\
\text { present discounted } \\
\text { value of social } \\
\text { benefits and costs. }\end{array}$ \\
\hline
\end{tabular}


Table 2: Log Wage Function Estimates for Ghana in 1987, 1988, 1991, and 1998, by Gender.

\begin{tabular}{|c|c|c|c|c|c|c|c|c|c|}
\hline & \multirow{2}{*}{$\begin{array}{l}\text { Years of } \\
\text { Schooling }\end{array}$} & \multicolumn{2}{|l|}{1987} & \multicolumn{2}{|l|}{1988} & \multicolumn{2}{|l|}{1991} & \multicolumn{2}{|l|}{1998} \\
\hline & & Male & Female & Male & Female & Male & Female & Male & Female \\
\hline \multicolumn{10}{|c|}{ Regression Coefficients (Omitted category is no schooling) } \\
\hline Some Primary & 4 & .289 & .203 & .219 & .389 & .241 & .303 & .337 & .098 \\
\hline Middle Certificate & 10 & .574 & .160 & .477 & .640 & .563 & .437 & .615 & .390 \\
\hline Secondary Certificate & 15 & 1.135 & .334 & 1.054 & 1.224 & 1.063 & .834 & 1.107 & 1.148 \\
\hline Commercial/Vocational & $5-12$ & .520 & .256 & .380 & .733 & .960 & .316 & .875 & .774 \\
\hline $\begin{array}{l}\text { Teacher/Nurse/ } \\
\text { Technical Certificate }\end{array}$ & 17 & 1.297 & 1.087 & 1.304 & 1.464 & 1.555 & 1.448 & 1.391 & 1.400 \\
\hline University & 19 & 1.701 & 1.409 & 1.779 & 1.398 & 1.778 & 1.721 & 2.098 & 1.143 \\
\hline Rural Resident & - & -.521 & -.557 & -.348 & -.596 & -.357 & -.484 & -.469 & -.461 \\
\hline $\mathbf{R}^{2}$ & - & .138 & .080 & .117 & .111 & .180 & .152 & .181 & .133 \\
\hline $\begin{array}{l}\text { Mean of Dependent Variable (log } \\
\text { hourly wage) } \\
\text { (Standard Deviation) } \\
\text { Sample Size } \\
\end{array}$ & & $\begin{array}{l}3.40 \\
(1.19) \\
1555 \\
\end{array}$ & $\begin{array}{l}3.19 \\
(1.36) \\
1444 \\
\end{array}$ & $\begin{array}{l}3.46 \\
(1.21) \\
1715 \\
\end{array}$ & $\begin{array}{l}3.16 \\
(1.42) \\
1617 \\
\end{array}$ & $\begin{array}{l}4.44 \\
(.991) \\
1989 \\
\end{array}$ & $\begin{array}{l}4.26 \\
(1.09) \\
1878 \\
\end{array}$ & $\begin{array}{l}6.06 \\
(1.15) \\
2669 \\
\end{array}$ & $\begin{array}{l}5.81 \\
(1.15) \\
2788 \\
\end{array}$ \\
\hline \multicolumn{10}{|c|}{ Implied Private Rate of Return in Percent per Annum } \\
\hline (Primary - None) & 4 & 7.2 & 5.1 & 5.5 & 9.7 & 6.0 & 7.6 & 8.4 & 2.5 \\
\hline (Middle - Primary) & 6 & 4.8 & -.7 & 4.3 & 4.2 & 5.4 & 2.2 & 4.6 & 4.9 \\
\hline (Secondary - Middle) & 5 & 11. & 2.6 & 12. & 12. & 10. & 8.0 & 9.8 & 15. \\
\hline (University - Secondary) & 4 & 14. & 27. & 18. & 4.4 & 18. & 22. & 25. & -0.1 \\
\hline
\end{tabular}

Also includes post-schooling experience and experience squared 
Table 3: Log Wage Function Estimates for Ghana 1987 and 1998, by Age and Gender.

\begin{tabular}{|c|c|c|c|c|c|c|c|c|c|}
\hline & \multirow{3}{*}{$\begin{array}{l}\text { Years of } \\
\text { Schooling }\end{array}$} & \multicolumn{4}{|l|}{1987} & \multicolumn{4}{|l|}{1998} \\
\hline & & \multicolumn{2}{|c|}{ Age 25-34 } & \multicolumn{2}{|c|}{ Age 35-44 } & \multicolumn{2}{|c|}{ Age 25-34 } & \multicolumn{2}{|c|}{ Age 35-54 } \\
\hline & & Male & Female & Male & Female & Male & Female & Male & Female \\
\hline \multicolumn{10}{|c|}{ Regression Coefficients (Omitted category is no schooling) } \\
\hline Some Primary & 4 & .359 & .249 & .261 & .250 & .425 & .301 & .311 & -.114 \\
\hline Middle Certificate & 10 & .585 & .412 & .615 & .132 & .660 & .502 & .625 & .175 \\
\hline Secondary Certificate & 15 & 1.321 & .815 & 1.160 & 1.041 & 1.243 & 1.178 & 1.073 & .991 \\
\hline Commercial/Vocational & $5-12$ & .832 & .615 & .357 & .247 & .849 & .758 & .905 & .584 \\
\hline $\begin{array}{l}\text { Teacher/Nurse } \\
\text { Technical Certificate }\end{array}$ & 17 & 1.567 & 1.487 & 1.173 & 1.147 & 1.392 & 1.534 & 1.413 & 1.125 \\
\hline University & 19 & 2.268 & 2.973 & 1.449 & 1.289 & 3.022 & 2.191 & 1.861 & .203 \\
\hline Rural Resident & - & -.533 & -.364 & -.513 & -.740 & -.537 & -.476 & -.435 & -.448 \\
\hline$\overline{R^{2}}$ & - & .125 & .057 & .151 & .104 & .164 & .123 & .190 & .150 \\
\hline $\begin{array}{l}\text { Mean of Dependent } \\
\text { Variable (log hourly wage) } \\
\text { (Standard Deviation) } \\
\text { Sample Size }\end{array}$ & & $\begin{array}{l}3.31 \\
(1.20) \\
672 \\
\end{array}$ & $\begin{array}{l}3.30 \\
(1.35) \\
676 \\
\end{array}$ & $\begin{array}{l}3.48 \\
(1.18) \\
883 \\
\end{array}$ & $\begin{array}{l}3.09 \\
(1.36) \\
768 \\
\end{array}$ & $\begin{array}{l}5.99 \\
(1.12) \\
938 \\
\end{array}$ & $\begin{array}{l}5.76 \\
(1.11) \\
1132 \\
\end{array}$ & $\begin{array}{l}6.10 \\
(1.17) \\
1731 \\
\end{array}$ & $\begin{array}{l}5.84 \\
(1.37) \\
1656 \\
\end{array}$ \\
\hline \multicolumn{10}{|c|}{ Implied Private Rate of Return in Percent per Annum } \\
\hline (Primary - None) & 4 & 9.0 & 6.2 & 6.5 & 6.3 & 11. & 7.5 & 7.8 & -2.9 \\
\hline (Middle - Primary) & 6 & 3.8 & 2.7 & 5.9 & -2.0 & 3.9 & 3.4 & 5.2 & 4.8 \\
\hline (Secondary - Middle) & 5 & 15. & 8.1 & 9.9 & 18. & 12. & 14. & 9.0 & 16. \\
\hline (University - Secondary) & 4 & 24. & 54. & 5.8 & 6.2 & 44. & 25. & 20. & $-20 .^{*}$ \\
\hline
\end{tabular}

Also includes post-schooling experience and experience squared

* Based on only a few females age 35-54 with a university degree and working for a wage in this year's sample survey. 
Table 4

Log Wage Function Estimates for Côte d'Ivoire in 1985-87, by Age and Gender

\begin{tabular}{|c|c|c|c|c|c|}
\hline & \multirow{2}{*}{$\begin{array}{l}\text { Years of } \\
\text { Schooling }\end{array}$} & \multicolumn{2}{|c|}{ Age 25-34 } & \multicolumn{2}{|c|}{ Age 35-54 } \\
\hline & & Male & Female & Male & Female \\
\hline \multicolumn{6}{|c|}{ Regression Coefficients (Omitted category is no schooling) } \\
\hline Some Primary & 4 & .342 & .353 & .483 & .674 \\
\hline Primary Certificate & 6 & .920 & .270 & 1.043 & .624 \\
\hline Middle Certificate & 10 & 1.474 & .653 & 1.502 & .775 \\
\hline Secondary Certificate & 12 & 1.903 & .887 & 2.013 & 1.333 \\
\hline Tech \& Professional & $6-11$ & .338 & .201 & .185 & .590 \\
\hline University & 17 & 2.703 & 1.069 & 2.191 & 2.754 \\
\hline Rural Resident & - & -.479 & -1.21 & -.718 & -1.35 \\
\hline $\mathbf{R}^{2}$ & - & .389 & .332 & .353 & .270 \\
\hline $\begin{array}{l}\text { Mean of Dependent } \\
\text { Variable (log hourly wage) } \\
\text { (Standard Deviation) } \\
\text { Sample Size }\end{array}$ & & $\begin{array}{l}5.71 \\
(2.14) \\
867 \\
\end{array}$ & $\begin{array}{l}5.10 \\
(2.79) \\
666 \\
\end{array}$ & $\begin{array}{l}5.63 \\
(2.11) \\
1355 \\
\end{array}$ & $\begin{array}{l}4.73 \\
(2.96) \\
928 \\
\end{array}$ \\
\hline \multicolumn{6}{|c|}{ Implied Private Rate of Return in Percent per Annum } \\
\hline (Primary - None) & 6 & 15. & 4.5 & 17. & 10. \\
\hline (Middle - Primary) & 4 & 14. & 9.6 & 12. & 3.8 \\
\hline (Secondary - Middle) & 2 & 22. & 12. & 26. & 28. \\
\hline (University - Secondary) & 5 & 16. & 3.6 & 3.6 & 28. \\
\hline
\end{tabular}

Also includes post-schooling experience and experience squared 
Table 5

Log Wage Function Estimates for Kenya in 1994, by Age and Gender

\begin{tabular}{|c|c|c|c|c|c|}
\hline & \multirow{2}{*}{$\begin{array}{l}\text { Years of } \\
\text { Schooling }\end{array}$} & \multicolumn{2}{|c|}{ Age 25-34 } & \multicolumn{2}{|c|}{ Age 35-54 } \\
\hline & & Male & Female & Male & Female \\
\hline \multicolumn{6}{|c|}{ Regression Coefficients ${ }^{\dagger}$ (Omitted category is no schooling) } \\
\hline Some Primary & 6 & .574 & .561 & .584 & .138 \\
\hline Middle Certificate & 8 & .857 & .651 & .814 & .462 \\
\hline Secondary Certificate & 12 & 1.151 & 1.397 & 1.279 & 1.206 \\
\hline Vocational/Tech & $10-14$ & 1.531 & 1.772 & 1.507 & 1.580 \\
\hline University & 16 & 1.983 & 2.452 & 1.784 & 1.858 \\
\hline Rural Resident & - & -.603 & -.943 & -.681 & -.901 \\
\hline $\mathbf{R}^{2}$ & - & .151 & .193 & .208 & .167 \\
\hline $\begin{array}{l}\text { Mean of Dependent } \\
\text { Variable (log hourly wage) } \\
\text { (Standard Deviation) } \\
\text { Sample Size }\end{array}$ & & $\begin{array}{l}2.27 \\
(1.17) \\
2625 \\
\end{array}$ & $\begin{array}{l}1.51 \\
(1.32) \\
2290 \\
\end{array}$ & $\begin{array}{l}2.22 \\
(1.26) \\
3401 \\
\end{array}$ & $\begin{array}{l}1.45 \\
(1.29) \\
2210\end{array}$ \\
\hline \multicolumn{6}{|c|}{ Implied Private Wage Returns in Percent per Annum } \\
\hline (Middle - None) & 8 & 11. & 8.1 & 10. & 5.8 \\
\hline (Secondary - Middle) & 4 & 7.4 & 20. & 12. & 19. \\
\hline (University - Secondary) & 4 & 21. & 26. & 13. & 16. \\
\hline
\end{tabular}

Also includes post-schooling experience and experience squared. 
Table 6 : Estimates of Wage Returns to Schooling by Level in South Africa in 1993, by Race, Gender and Age $\downarrow$

\begin{tabular}{|c|c|c|c|c|c|c|c|c|c|}
\hline & \multirow{3}{*}{$\begin{array}{l}\text { Years of } \\
\text { Schooling }\end{array}$} & \multicolumn{4}{|c|}{ Africans } & \multicolumn{4}{|c|}{ Whites } \\
\hline & & \multicolumn{2}{|l|}{$25-34$} & \multicolumn{2}{|l|}{$35-54$} & \multicolumn{2}{|l|}{$25-34$} & \multicolumn{2}{|l|}{$35-54$} \\
\hline & & Male & Female & Male & Female & Male & Female & Male & Female \\
\hline \multicolumn{10}{|c|}{ Regression Coefficients (Omitted Category is no schooling) } \\
\hline Some & 6-8 & .293 & .348 & .465 & .636 & .083 & .309 & .734 & -.246 \\
\hline Junior Secondary & 10 & .728 & .986 & .872 & 1.291 & .142 & -.345 & .195 & -.315 \\
\hline Secondary & 12 & 1.184 & 1.614 & 1.245 & 1.869 & .546 & .215 & .668 & -.069 \\
\hline Technical/Nurse/Teacher & $12-14$ & 1.819 & 2.510 & 1.752 & 2.553 & .870 & .337 & .793 & .281 \\
\hline University & 16 & 2.448 & 3.438 & 2.389 & 2.908 & 1.365 & .713 & 1.137 & .488 \\
\hline Rural & - & -.476 & -.339 & -.555 & -.394 & -.227 & -.461 & -.040 & -.031 \\
\hline $\mathbf{R}^{2}$ & - & .360 & .450 & .346 & .469 & .247 & .204 & .151 & .249 \\
\hline $\begin{array}{l}\text { Mean of Dependent Variable } \\
\text { (log hourly wage) } \\
\text { (Standard Deviation) } \\
\text { Sample Size }\end{array}$ & & $\begin{array}{l}1.46 \\
(.890) \\
850\end{array}$ & $\begin{array}{l}1.12 \\
(1.09) \\
541\end{array}$ & $\begin{array}{l}1.53 \\
(.979) \\
1115\end{array}$ & $\begin{array}{l}1.08 \\
(1.07) \\
767\end{array}$ & $\begin{array}{l}3.19 \\
(.598) \\
214\end{array}$ & $\begin{array}{l}2.75 \\
(.612) \\
192\end{array}$ & $\begin{array}{l}3.41 \\
(.746) \\
317\end{array}$ & $\begin{array}{l}2.79 \\
(.526) \\
541\end{array}$ \\
\hline \multicolumn{10}{|c|}{ Implied Private Rate of Return in Percent per Annum } \\
\hline Junior Secondary - None & 10 & 7.3 & 9.6 & 8.8 & 13. & 1.4 & -3.4 & 1.9 & -3.1 \\
\hline Secondary - Junior Secondary & 2 & 22. & 32. & 18. & 28. & 20. & 28. & 24. & 12. \\
\hline University - Secondary & 4 & 32. & 46. & 29. & 26. & 20. & 12. & 12. & 14. \\
\hline
\end{tabular}

$\uparrow$ The wage analyzed here is based on the sample for which the cash wage is positive and expressed as an hourly cash wage. A few additional individuals also report income in-kind (food, housing, transportation, etc.). Summing these cash and in-kind income per hour leads to a wage with more outlying values that are less plausible, perhaps because the units of time, such as per day, leads to some large and some very small in-kind wage rates per hour. 
Table 7: Spline Estimates of Wage Returns to Schooling in Nigeria: 1996-1999

\begin{tabular}{|c|c|c|c|c|c|c|c|c|}
\hline \multirow{2}{*}{$\begin{array}{c}\text { Age Group } \\
\text { Sex }\end{array}$} & \multicolumn{2}{|c|}{$15-64$} & \multicolumn{2}{|c|}{$25-34$} & \multicolumn{2}{|c|}{$35-44$} & \multicolumn{2}{|c|}{$45-64$} \\
\hline & Male & Female & Male & Female & Male & Female & Male & Female \\
\hline \multicolumn{9}{|c|}{ Spline estimates of Wage Return per year of Schooling } \\
\hline $\begin{array}{l}\text { Primary School } \\
(1-6)\end{array}$ & .025 & .024 & .016 & .008 & .013 & .021 & .041 & .045 \\
\hline $\begin{array}{l}\text { Secondary School } \\
(1-6)\end{array}$ & .039 & .044 & .040 & .072 & .039 & .031 & .042 & .042 \\
\hline $\begin{array}{l}\text { Post-Secondary } \\
\text { School (1-4) }\end{array}$ & .104 & .122 & .127 & .138 & .120 & .136 & .095 & .100 \\
\hline $\begin{array}{l}\text { Sample Wage } \\
\text { Earners }\end{array}$ & 9,065 & 3,135 & 2,657 & 1,273 & 3,330 & 1,079 & 2,710 & 454 \\
\hline Sample All Persons & 100,872 & 104,864 & 21,433 & 31,772 & 21,819 & 23,040 & 27,129 & 17,908 \\
\hline \multicolumn{9}{|c|}{ Means of Schooling of Wage Earner Samples } \\
\hline Primary & 5.38 & 5.40 & 5.58 & 5.66 & 5.50 & 5.41 & 5.09 & 4.59 \\
\hline Secondary & 3.98 & 4.29 & 4.39 & 4.58 & 4.16 & 4.31 & 3.46 & 3.48 \\
\hline Post Secondary & 0.64 & 0.76 & 0.52 & 0.74 & 0.75 & 0.94 & 0.70 & 0.81 \\
\hline Total Years & 10.00 & 10.49 & 10.50 & 10.99 & 10.42 & 10.67 & 9.26 & 8.89 \\
\hline \multicolumn{9}{|l|}{ Means All Persons } \\
\hline $\begin{array}{l}\text { Total Years of } \\
\text { Schooling }\end{array}$ & 5.19 & 3.53 & 5.75 & 3.41 & 4.44 & 2.61 & 3.07 & 1.65 \\
\hline
\end{tabular}

Source: Aromolaran(2002). 
Table 8: Estimates of Private Wage Returns to Schooling in Burkina: 1994, 1998

\begin{tabular}{|c|l|l|l|l|}
\hline & \multicolumn{2}{|c|}{1994} & \multicolumn{2}{c|}{1998} \\
\hline $\begin{array}{l}\text { Spline Coefficients on Years of } \\
\text { Schooling: }\end{array}$ & Male & Female & Male & Female \\
\hline Primary (1-6) & 0.101 & 0.190 & 0.079 & 0.071 \\
\hline Secondary (-7) & & & & \\
\hline Post Secondary (2) & 0.172 & 0.161 & 0.109 & 0.144 \\
\hline Rural Resident & 0.174 & 0.192 & 0.129 & 0.160 \\
\hline R2 & -0.020 & -0.170 & -0.012 & 0.079 \\
\hline $\begin{array}{l}\text { Mean of Dependant Variable } \\
\text { (log of Monthly Wage in CFA) }\end{array}$ & 10.63 & 10.57 & 10.64 & 10.64 \\
\hline $\begin{array}{l}\text { (Standard Deviation) } \\
\text { Sample Size of Wage Earners }\end{array}$ & 1253 & 269 & 1265 & 284 \\
\hline
\end{tabular}

Source: Kaizianga (2002) 
Table 9: Proportion of Children with Any Higher Education in Ghana and Côte d'Ivoire, by Child Age, Sex and Parents' Education

\begin{tabular}{|c|c|c|c|c|c|c|c|c|}
\hline \multirow[b]{2}{*}{ Ghana 1987-88 } & \multicolumn{4}{|c|}{ Sons by Age } & \multicolumn{4}{|c|}{ Daughters by Age } \\
\hline & $25-34$ & $35-44$ & $45-54$ & $55+$ & $25-34$ & $35-44$ & $45-54$ & $55+$ \\
\hline $\begin{array}{l}\text { All Persons } \\
\text { (Sample Size) }\end{array}$ & $\begin{array}{l}.067 \\
(1722)\end{array}$ & $\begin{array}{l}.088 \\
(1188)\end{array}$ & $\begin{array}{l}.048 \\
(876)\end{array}$ & $\begin{array}{l}.018 \\
(1140)\end{array}$ & $\begin{array}{l}.018 \\
(2205)\end{array}$ & $\begin{array}{l}.023 \\
(1299)\end{array}$ & $\begin{array}{l}.010 \\
(1077)\end{array}$ & $\begin{array}{l}.004 \\
(1353)\end{array}$ \\
\hline \multicolumn{9}{|c|}{ Father's Highest Education } \\
\hline None & .053 & .061 & .035 & .012 & .007 & .010 & .005 & .002 \\
\hline Primary $^{a}$ & .091 & .245 & .095 & .076 & .041 & .076 & .028 & .028 \\
\hline Secondary ${ }^{\mathrm{a}}$ or more & .238 & .176 & .462 & .400 & .083 & .171 & .143 & .000 \\
\hline \multicolumn{9}{|c|}{ Mother's Highest Education } \\
\hline None & .059 & .077 & .045 & .015 & .015 & .014 & .006 & .002 \\
\hline Primary & .148 & .295 & .091 & .091 & .051 & .154 & .143 & .103 \\
\hline Secondary or more & .417 & 1.00 & 1.00 & 1.00 & .120 & .455 & .333 & .000 \\
\hline \multicolumn{9}{|l|}{ Côte d'Ivoire $1985-87$} \\
\hline $\begin{array}{l}\text { All Persons } \\
\text { (Sample Size) }\end{array}$ & $\begin{array}{l}.111 \\
(2000)\end{array}$ & $\begin{array}{l}.066 \\
(1301)\end{array}$ & $\begin{array}{l}.022 \\
(1161)\end{array}$ & $\begin{array}{l}.004 \\
(1535) \\
\end{array}$ & $\begin{array}{l}.028 \\
(2605)\end{array}$ & $\begin{array}{l}.007 \\
(1835)\end{array}$ & $\begin{array}{l}.002 \\
(1395)\end{array}$ & $\begin{array}{l}.001 \\
(1405) \\
\end{array}$ \\
\hline \multicolumn{9}{|c|}{ Father's Highest Education } \\
\hline None & .085 & .054 & .017 & .003 & .009 & .004 & .001 & .000 \\
\hline Primary $^{b}$ & .272 & .170 & .083 & .000 & .140 & .077 & .080 & .143 \\
\hline Secondary ${ }^{\mathrm{b}}$ or more & .301 & .304 & .429 & .667 & .404 & .150 & .000 & .000 \\
\hline \multicolumn{9}{|c|}{ Mother's Highest Education } \\
\hline None & .105 & .064 & .020 & .004 & .020 & .007 & .002 & .001 \\
\hline Primary & .257 & .222 & .000 & & .289 & .000 & .000 & .000 \\
\hline Secondary or more & .778 & 1.00 & 1.00 & & .733 & .333 & & \\
\hline
\end{tabular}

Mean is based on a cell of less than ten persons

Cell is empty

aPrimary and Middle combined for first tens years of primary, followed by five years of Secondary.

bPrimary is six years and Secondary is six years. 
Table 10

Educational attainment of Respondents Age 25-54, Fitted to Geographic Areas of Residence and Father's and Mother's Schooling

(absolute values of $t$ ratios reported in parentheses beneath regression coefficients)

\begin{tabular}{|c|c|c|c|c|}
\hline & \multicolumn{2}{|c|}{ Ghana 1987-88 } & \multicolumn{2}{|c|}{ Côte d'Ivoire 1985-87 } \\
\hline & Male & Female & Male & Female \\
\hline \multicolumn{5}{|l|}{ Regression Coefficients a } \\
\hline $\begin{array}{l}\text { Rural } \\
\text { (other urban omitted category) }\end{array}$ & $\begin{array}{l}-2.94 \\
(16 .) \\
\end{array}$ & $\begin{array}{l}-1.86 \\
(14 .)\end{array}$ & $\begin{array}{l}-2.79 \\
(18 .)\end{array}$ & $\begin{array}{l}-9.07 \\
(10.9)\end{array}$ \\
\hline Capital City & $\begin{array}{l}1.54 \\
(6.09)\end{array}$ & $\begin{array}{l}1.66 \\
(8.57)\end{array}$ & $\begin{array}{l}1.24 \\
(6.98)\end{array}$ & $\begin{array}{l}(13 .) \\
.333\end{array}$ \\
\hline Mother's Schooling Years & $\begin{array}{l}.130 \\
(3.04)\end{array}$ & $\begin{array}{l}.294 \\
(10.4)\end{array}$ & $\begin{array}{l}.233 \\
(2.35)\end{array}$ & $\begin{array}{l}.333 \\
(6.67)\end{array}$ \\
\hline Father's Schooling Years & $\begin{array}{l}300 \\
(13 .) \\
\end{array}$ & $\begin{array}{l}318 \\
(20 .)\end{array}$ & $\begin{array}{l}.521 \\
(16 .)\end{array}$ & $\begin{array}{l}.615 \\
(29 .)\end{array}$ \\
\hline Age Years & $\begin{array}{l}.400 \\
(4.81)\end{array}$ & $\begin{array}{l}.161 \\
(4.14)\end{array}$ & $\begin{array}{l}.300 \\
(4.07)\end{array}$ & $\begin{array}{l}-1.90 \\
(4.90)\end{array}$ \\
\hline Age Squared/100 & $\begin{array}{l}-.746 \\
(5.89)\end{array}$ & $\begin{array}{l}-.373 \\
(4.14)\end{array}$ & $\begin{array}{l}-.541 \\
(5.66)\end{array}$ & $\begin{array}{l}.158 \\
(3.14)\end{array}$ \\
\hline $\mathbf{R}^{2}$ & .234 & .343 & .311 & .369 \\
\hline Sample Size & 3643 & 4419 & 4451 & 5838 \\
\hline $\begin{array}{l}\text { Mean of Schooling Years } \\
\text { [Standard Deviation] }\end{array}$ & $\begin{array}{l}7.16 \\
{[5.64]}\end{array}$ & $\begin{array}{l}3.80 \\
{[4.91]}\end{array}$ & $\begin{array}{l}3.77 \\
{[5.01]}\end{array}$ & $\begin{array}{l}1.29 \\
{[3.15]}\end{array}$ \\
\hline
\end{tabular}

a Also included dummies for year of survey and whether the education of the mother or father is missing, in which case the parent education is set equal to the mean of parents reporting in the sample. 


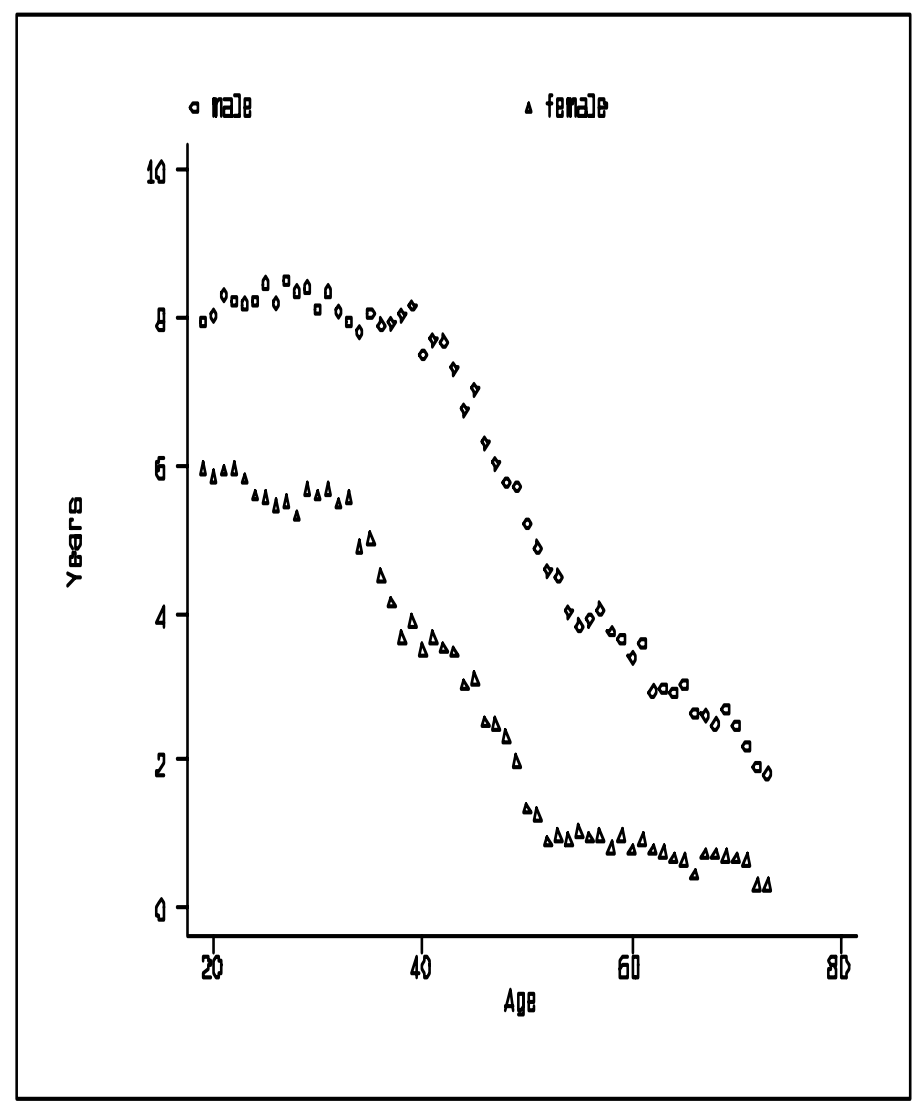

Figure 1.

Average Schooling Completed in Ghana by Age and Sex : 1987/88 


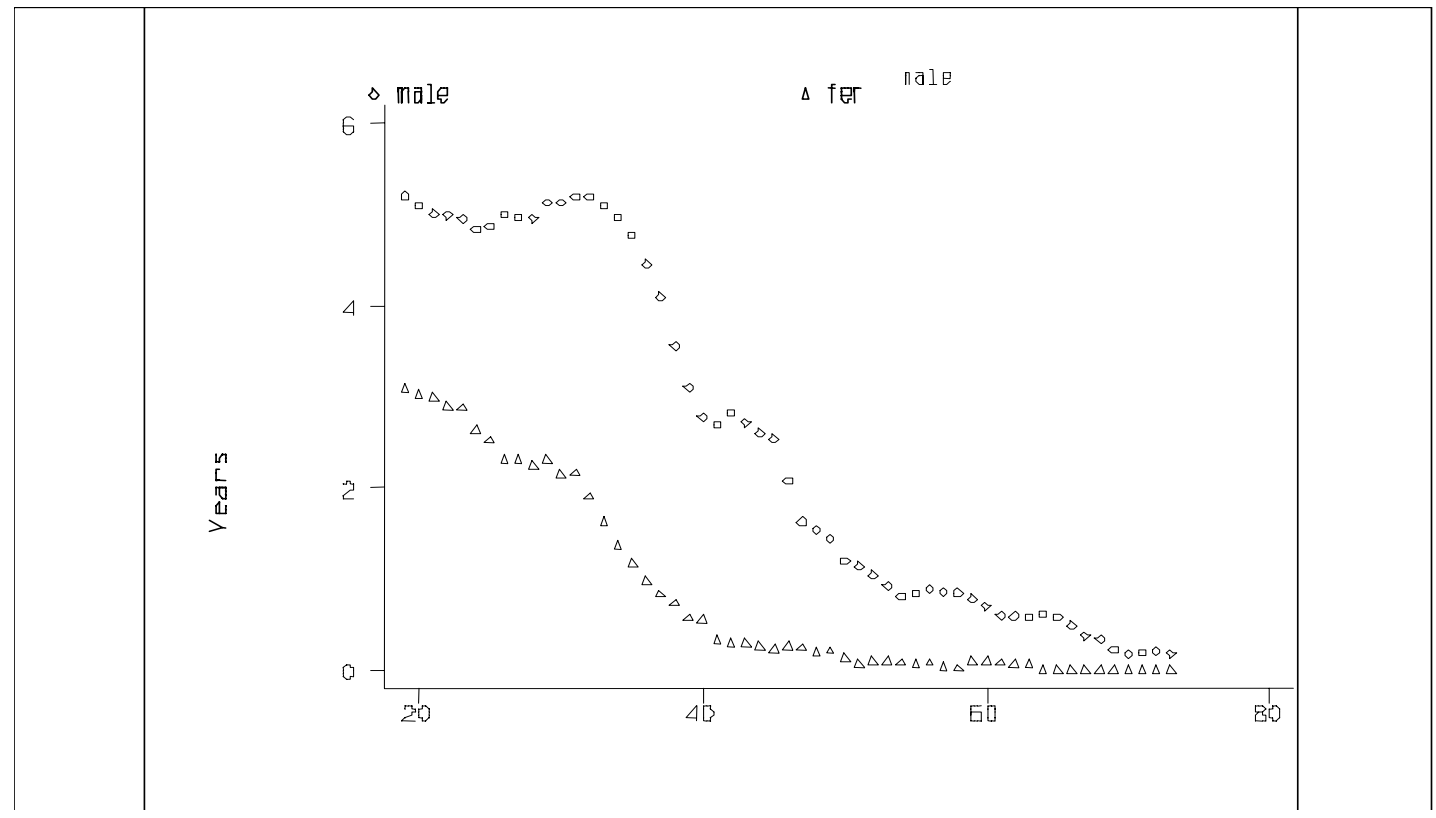

Figure 2.

Average Schooling Completed in Côte d'Ivoire by Age and Sex : 1985/86 


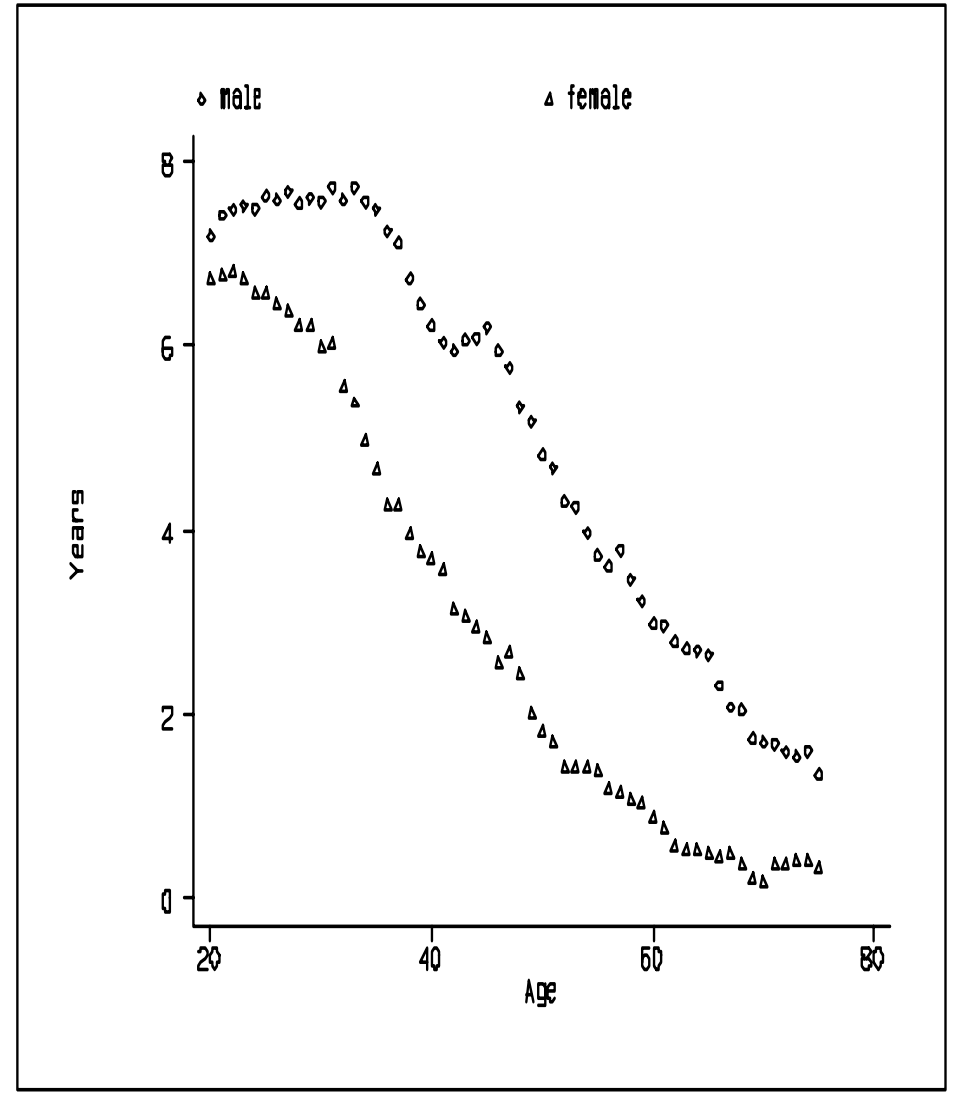

Figure 3.

Average Schooling Completed in Kenya by Age and Sex : 1994 


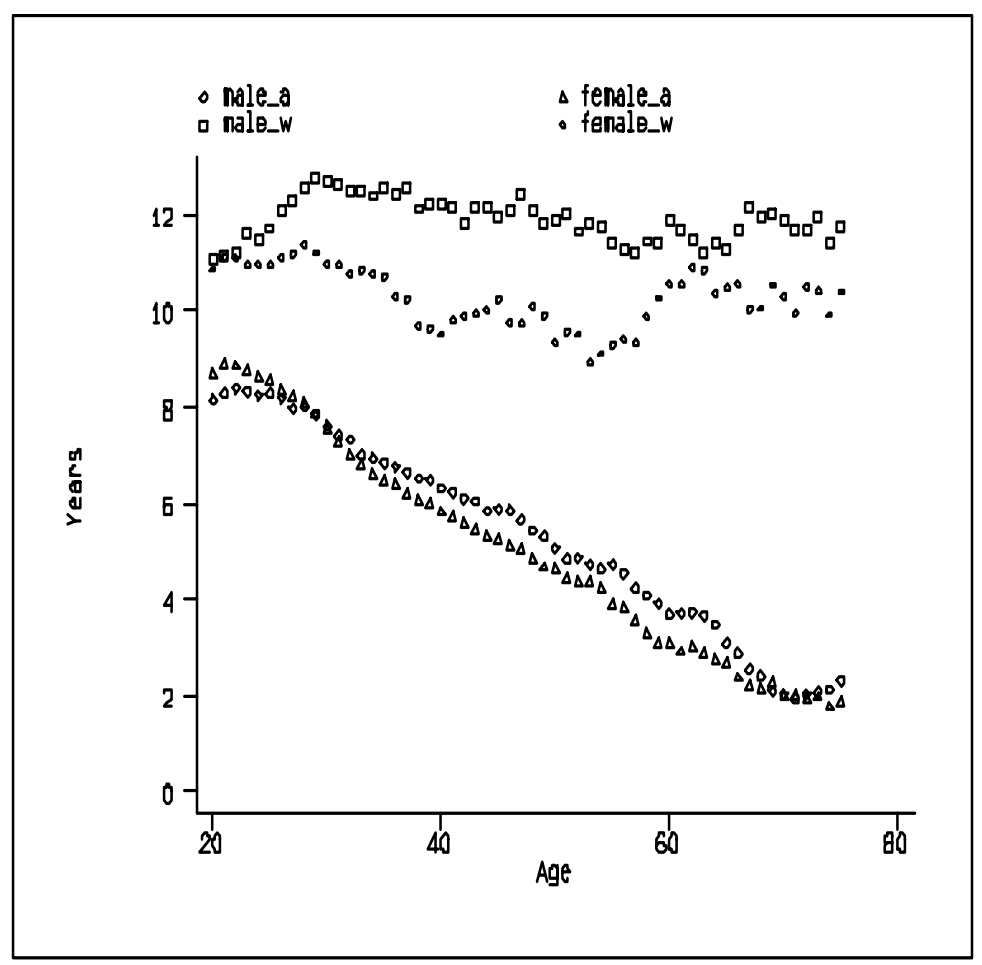

Figure 4.

Average Schooling Completed in South Africa by Age, Sex, and Africans and Whites 


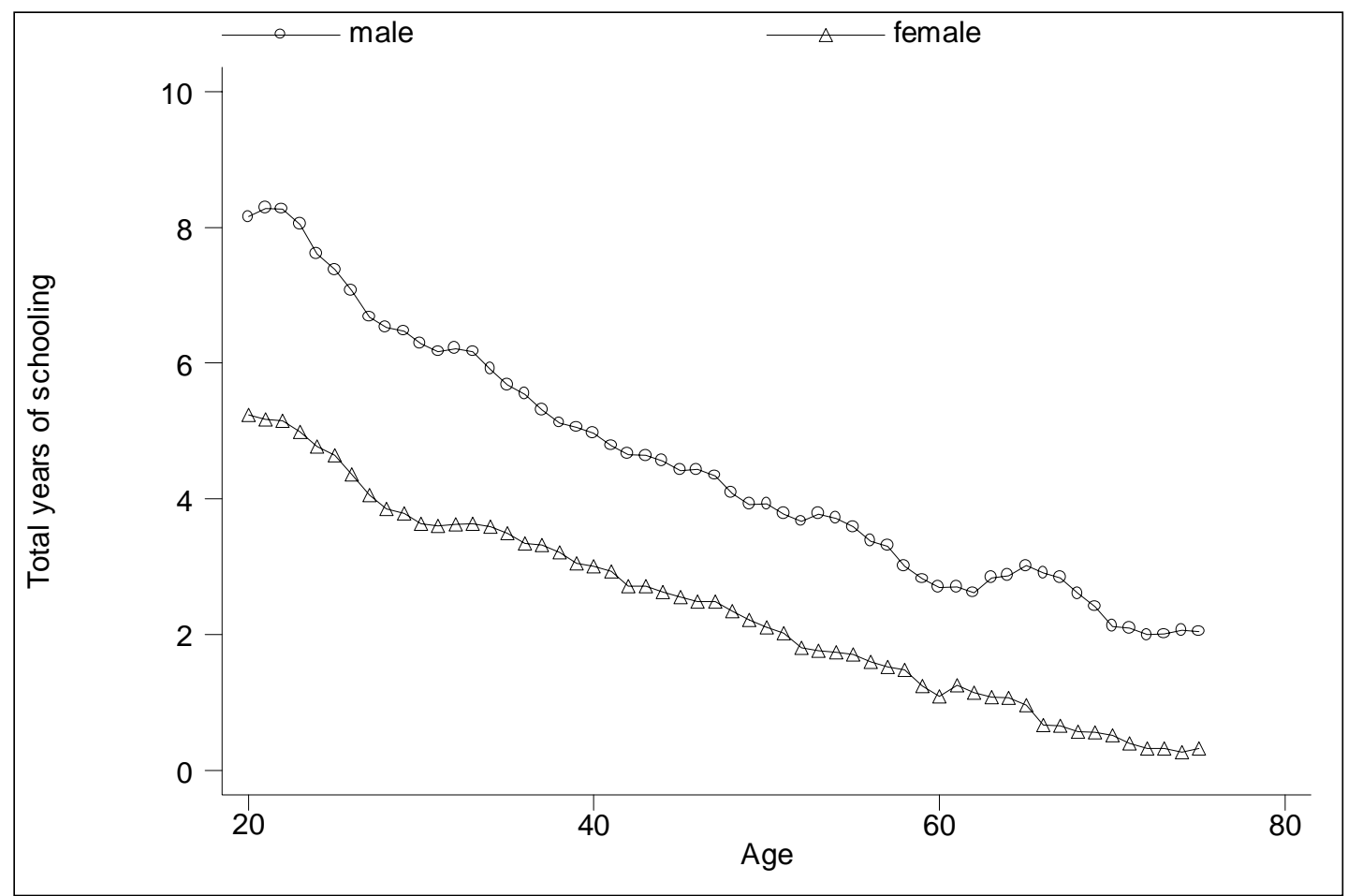

Figure 5.

Average Schooling Completed in Nigeria by Age and Sex : 1996-99 


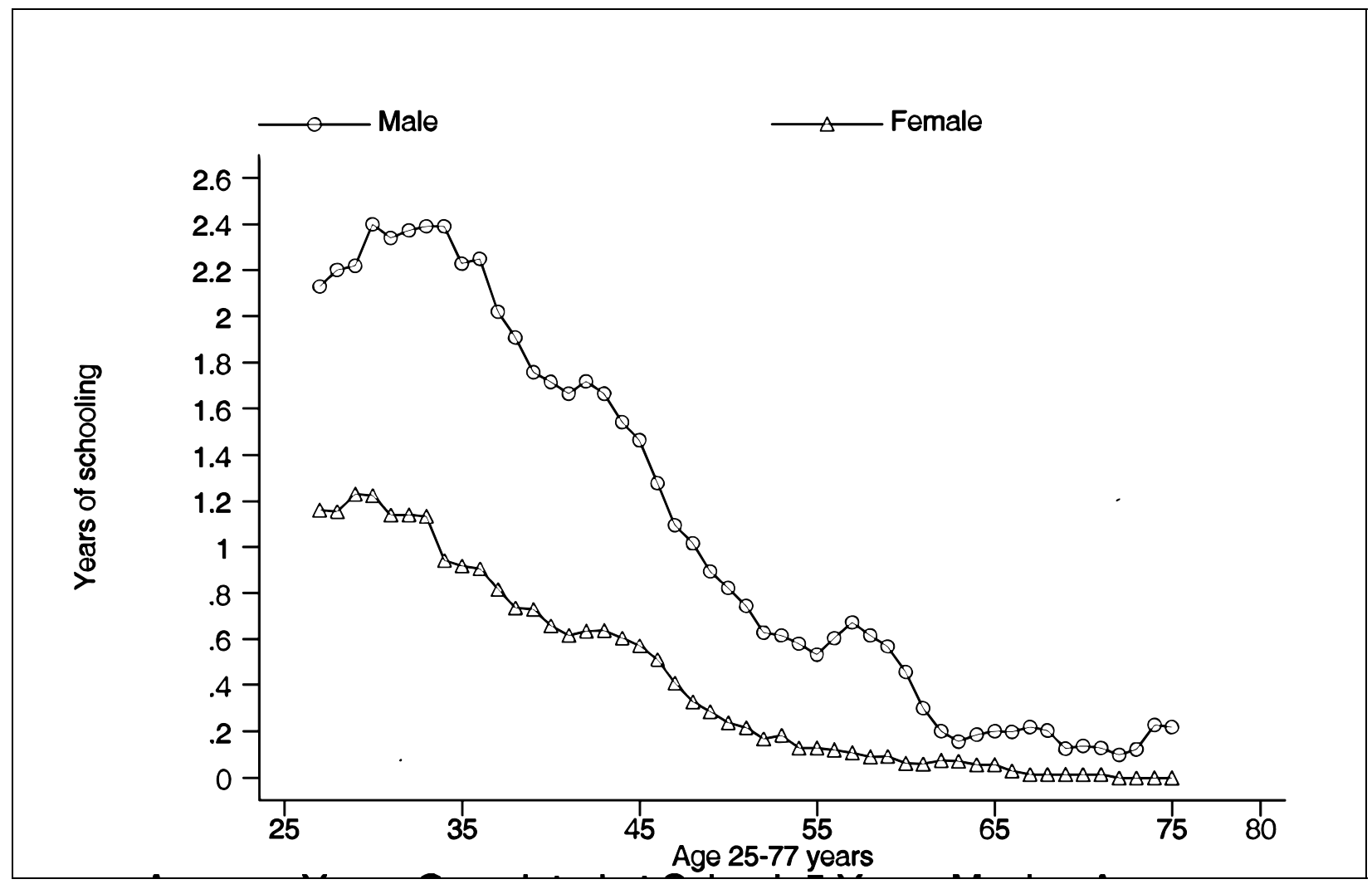

Figure 6.

Average Schooling Completed in Burkina by Age and Sex: 1994 
References:

Acemoglu, D., (2002),”Technical Change, Inequality, and the Labor Market”, Journal of Economic Literature, 40(1): 7-72.

Ainsworth, M. and D. Filmer (2002), “Poverty, AIDS and Children's Schooling: A Targeting Dilemma”, World Bank Research Working Paper 2885, Washington D.C.

Ainsworth, M. and M. Over(1997), Confronting AIDS, World Bank Staff Report , Oxford University Press, New York.

Albrecht, D. and A. Ziderman (1991), “Deferred Cost Recovery for Higher Education,” Discussion Paper No. 137, Washington, D.C.: World Bank.

Arends-Kuenning, M. and S. Amin (2000), “The Effects of Schooling Incentive Programs on Household Resource Allocation in Bangladesh,” Policy Research Division, Working Paper 133, Population Council, New York City.

Armolaran, A.B.(2002), “Private Wage Returns to Schooling in Nigeria: 1996- 1999”, Discussion Paper No. 849, Economic Growth Center, Yale University, New Haven CT.

Becker, G.S. (1964), Human Capital, New York: Columbia University Press.

Berthelmey, C. and F. Bourguignon (1996), Growth and Crisis in Côte d'Ivoire, Washington, D.C., The World Bank.

Bhagwati, J. and M. Partington (eds.) (1976), Taxing the Brain Drain, Amsterdam: North Holland Publishing Company.

Binswanger, H.P. and M.R. Rosenzweig (eds) (1984) Contractual Arrangements, Employment and Wages in Rural Labor Markets in Asia, New Haven, CT: Yale University Press.

Boissiere, M., J.B. Knight and R.H. Sabot (1985), “Earnings, Schooling, Ability and Cognitive Skills,” American Economic Review, 75:1026-30.

Boozer, M.A. and T.J. Philipson (2000), “The Impact of Public Testing for Human Immmunodeficiency Virus”, Journal of Human Resources, 35(3): 419-446.

Card, D. (1999), “The Causal Effects of Education on Earnings,” in Handbook of Labor Economics, Vol. 3, O. Ashenfelter and D. Card (eds.), Amsterdam, North Holland Publishing Company.

Card, D. (2001), “Estimating the Returns to Schooling: Progress on Some Persistent Problems,” Econometrica, 69(5):1127-1160.

Chattopadhay, E., and E. Duflo (2001), “Women's Leadership and Policy Decisions: Evidence from a Nationwide Randomized Experiment in India,” MIT Discussion Paper, Cambridge, MA.

Colclough, C. (1997), Marketing Education and Health in Developing Countries, Clarendon Press, Oxford University Press.

Denison, E.F. (1962), Sources of Economic Growth in the United States and the Alternatives Before Us, Supple. Paper No. 13, New York, Committee for Economic Development.

De Walque, D. (2002), “How does the impact of an HIV/AIDS Information Campaign Vary with Educational Attainment?”, Working Paper forthcoming Population Research Center, NORC, University of Chicago.

Duflo, E. (2001), “Schooling and Labor Market Consequences of School Construction in Indonesia,” American Economic Review, 91(4):795-813. 
Easterly, W. (2001), The Elusive Quest for Growth, Cambridge, MA: MIT Press.

Fei, J.C. and G. Ranis (1964), Development of the Labor Surplus Economy: Theory and Policy, Homewood, IL: Richard D. Irwin, Inc.

Foster, A. and M. Rosenzweig (1995), “Learning by Doing and Learning from Others: Human Capital and Technical Change in Agriculture,” Journal of Political Economy, 103(6):1176-1209.

Gertler, P., D.I. Levine, and M. Ames (2002), “Schooling and Parental Death” Economic Research Network, September 2002, UC Berkeley

Harris, J. and M. Todaro (1970), “Migration, Unemployment and Development,” American Economic Review, 60(1):126-142.

Heckman, J.J. (1979), “Sample Selection Bias as a Specification Error”, Econometrica, 47: 153-163.

Hinchliffe, K. (1993), “Neo-Liberal Prescription for Education Finance: Unfortunately Necessary or Inherently Undesirable?” International Journal of Educational Development 13(2):183-187.

Jacoby, H.G. and E. Skoufias (1997), "Risk, Financial Markets, and Human Capital in a Developing Country," Review of Economic Studies, 64:311-335 (July).

Jimenez, E. (1987), Pricing Policies in Social Sectors: Cost Recovery for Education and Health in Developing Countries, Baltimore, MD: Johns Hopkins University Press.

Johnstone, D. (1992), “International Comparisons of Student Financial Support,” in Woodhall (ed.), $\underline{\text { Higher }}$ Education, 23(4).

Jorgenson, D.W. (1995), Productivity, Vol. I , Postwar U.S. Economic Growth, Cambridge, MA: MIT Press.

Katz, L.F. and D.H.Autor (1999), “Changes in the Wage Structure and Earnings Inequality” in Handbook of Labor Economics, vol 3A, (eds.) O. Ashenfelter and D. Card, Elsevier Science : Amsterdam.

Kazianga, H. (2002), “ Schooling Returns for Wage Earners in Burkina Faso: Evidence from the 1994 and 1998 Living Standard Measurement Surveys”, duplicated, Economic Growth Center, Yale University, New Haven CT.

Kelly, M.J. (2001), “Challenging the Challenger” University of Zambia and World Bank (www.adeanet.org/publicatons/wghe/univ_aids-rept_en.html)

Kim, S. and J-H. Lee (2001), "Demand for Education and Developmental State: Private Tutoring in South Korea," Social Science Research Electronic Paper Collection - id=268284.

Kimalu, P.K., N. Nafula, D.K. Manda, G. Mwabu and M.S. Mimeyi (2001), "Kenyan Public Education Sector: Structure and Performance,” paper prepared for Kenyan Institute of Public Policy Research and Analysis, Nairobi.

King, E.M. (1997), “Who Pays for Education in Indonesia,” in Marketizing Education and Health in Developing Countries (ed.) C. Colclough, Clarendon Press, Oxford University Press.

Knight, J.B. and R. H. Sabot (1981), “The Returns to Education: Increasing with Experience and Decreasing in Expansion,” Oxford Bulletin of Economics and Statistics 43(1):51-71.

Knight, J.B. and R. H. Sabot (1990), Education, Skills and Inequality: The East Africa Natural Experiment, New York, NY: Oxford University Press.

Kuznets, S. (1966), Modern Economic Growth: Rate, Structure and Spread, New Haven, CT: Yale University Press. 
Lewis, A. (1954), “Economic Development with Unlimited Supplies of Labor,” The Manchester School, May.

Lochner, L. and E. Moretti, 2001, “The Effect of Education on Crime”, National Bureau of Economic Research working paper no. 8609, Cambridge MA: NBER.

Lucas, R. (1988), “On the Mechanics of Economic Developments,” Journal of Monetary Economics, 22(1):3-22.

Mincer, J. (1974), Schooling, Experience and Earnings, New York: Columbia University Press.

Murphy, K.M. and F. Welch (1992), “The Structure of Wages”, Quarterly Journal of Economics, 107(1): 285-326.

Mwabu, G. and T.P. Schultz (2000), “Wage Premiums for Education and Location of Workers in South Africa, by Gender and Race,” Economic Development and Cultural Change, 60(1):126-142. (1998 Economic Growth Center Discussion Paper No. 785 includes appendix tables).

Nerlove, M. (1975), “Some Problems in the Use of Income-Contingent Loans for the Finance of Higher Education,” Journal of Political Economy, 83:157-83.

Psacharapoulos, G. and M. Woodhall (1985), Education for Development, New York: Oxford University Press.

Psacharopoulos, G. and H. A. Patrinos (2002), “Returns to Investment in Education: A Further Update”, World Bank Policy Research, working paper 2881: Washington D.C.

Romer, P.M. (1986), “Increasing Returns and Long Run Growth,” Journal of Political Economy, 94(3):1002-37 (October).

Schultz, T.P. (1987), “School Expenditures and Enrollments 1960-1980: The Effects of Income, Prices and Population Growth” in National Academy of Sciences report on Population Growth and Economic Development, Madison WI: University of Wisconsin Press.

Schultz, T.P. (1988), “Education Investments and Returns,” in Handbook of Development Economics, (eds.) H. Chenery and T.N. Srinivasan, Amsterdam: North Holland Publishing Company.

Schultz, T.P. (1995), Investment in Women's Human Capital, Chicago, IL: University of Chicago Press.

Schultz, T.P. (2001), “School Subsidies for the Poor: Evaluating the Mexican Progresa Poverty Program,” Economic Growth Center Discussion Paper No. 834, New Haven, CT: Yale University (forthcoming Journal of Development Economics).

Schultz, T.P. (2002), “Why Governments Should Invest More to Educate Girls,” World Development. 30(2) 207225.

Schultz, T.P. and A. Tansel (1997), Wage and Labor Supply Effects of Illness in Cote d'Ivoire and Ghana”, Journal of Development Economics, 53(2): 251-286.

Schultz, T.W. (1961), “Investments in Human Capital,” American Economic Review, 51(1):1-17.

Schultz, T.W. (1975), “The Ability to Deal with Disequilibria”, Journal of Economic Literature, 13(3): 827-846.

Sedlacek, G. (2001), “Three-in-One Social Policy: Insurance, Assistance and Investment Through Latin America’s Conditional Targeted Transfers,” Washington, D.C.: Inter-American Development Bank.

Tang, W. and W.L. Parish (2000), Chinese Urban Life Under Reform, Cambridge : Cambridge University Press.

Tilak, J.B.G. (1997), “Cost Recovery in Education,” in Marketizing Education and Health in Developing Countries, (ed.) C. Colclough, Clarendon Press, Oxford University Press.

Topel, R. (1999), “Labor Markets and Economic Growth,” in Handbook of Labor Economics, (eds.) O. Ashenfelter and D. Card, Volume 3C, Chapter 44, Amsterdam: Elsevier. 
Woodhall, M. (ed.), (1992), “Student Loans in Developing Countries,” Higher Education, Special Issue 23(4).

World Bank. (1986) World Development Report (WDR), New York, NY: Oxford University Press.

World Bank (2000), Higher Education in Developing Countries, The Task Force on Higher Education and Society, Washington, D.C.

World Bank. (2001) World Development Report (WDR), New York, NY: Oxford University Press. 